\title{
SYNTHESIS AND CHARACTERIZATION OF SURFACE SULFONATED
}

POLYPROPYLENE FILMS

\author{
A THESIS SUBMITTED TO \\ THE GRADUATE SCHOOL OF NATURAL AND APPLIED SCIENCES \\ $\mathrm{OF}$
}

THE MIDDLE EAST TECHNICAL UNIVERSITY

BY

SAFIYE TUBA ECEVIT

IN PARTIAL FULFILLMENT OF THE REQUIREMENTS FOR THE DEGREE OF MASTER OF SCIENCE

IN

THE DEPARTMENT OF POLYMER SCIENCE AND TECHNOLOGY

MARCH 2004 
Approval of the Graduate School of Natural and Applied Science

Prof. Dr. Canan Özgen

Director

I certify that this thesis satisfies all the requirements as a thesis for the degree of Master of Science.

Prof. Dr. Ali Usanmaz

Head of Department

This is to certify that we have read this thesis and that in our opinion it is fully adequate, in scope and quality, as a thesis for the degree of Master of Science.

Prof. Dr. Leyla Aras

Supervisor

Examining Committee Members

Prof. Dr. Erdal Bayramlı (Chairman)

Prof. Dr. Leyla Aras

Prof. Dr.Teoman Tinçer

Prof. Dr. Ali Usanmaz

Assist.Prof. Dr. Göknur Bayram
Prof. Dr. Teoman Tinçer

Co- Supervisor 


\begin{abstract}
SYNTHESIS AND CHARACTERIZATION OF SURFACE SULFONATED POLYPROPYLENE FILMS
\end{abstract}

\author{
Ecevit, Safiye Tuba \\ M.S., The Department of Polymer Science and Technology \\ Supervisor: Leyla Aras, Prof. Dr. \\ Co- Supervisor: Teoman Tinçer, Prof. Dr.
}

March 2004, 44 pages

The basic reseach on the surface sulfonation of the polypropylene is very important due to the surface design for higher functionalization.

For this purpose, liquid-phase sulfonation of the polypropylene surfaces at various temperatures for different time periods were performed by concentrated sulphuric acid. The physical and chemical changes formed by the effect of the sulfonation on the polypropylene surfaces were determined by contact angle 
measurement, mechanical analysis, UV-Vis spectrometer, differential scanning calorimeter (DSC) and scanning electron microscopy (SEM).

The surface polarity and wetting properties of the samples were evaluated by contact angle measurement. It is seen that, sulfonation at low temperatures and short time periods improve these two properties of the polypropylene surfaces. Sulfonation at high temperatures and long time periods however, cause the partial breakdown of the polymer by degradation.

Noticeable color change due to the degradation and carbonization of the polypropylene films sulfonated at high temperature and long time were supported by the $\mathrm{UV}-\mathrm{Vis}$ spectra of the samples.

Mechanical properties of sulfonated PP films were investigated. Consequently, after the sulfonation process the mechanical properties of the PP films showed a general trend of decrease with sulfonation time for a given temperature and a very fast decrease at high temperature of sulfonation.

Thermal characteristics were found by differential scanning calorimeter (DSC). Thermal analysis revealed that sulfonated PP film samples displayed an additional endothermic peak.

The physical effects of the sulfonation were examined by scanning electron microscopy (SEM) which showed a hexagonal hole formations due to the bursting of the air bubbles within the PP films by the effect sulfonation. The lamelae formations were also seen around these holes.

Keywords: Polypropylene, Surface modification, Surface sulfonation, Surface Sulfonation of Polypropylene 


\title{
ÖZ
}

\section{YÜZEYİ SÜLFONLANMIŞ POLIPROPILEN FILMLERININ SENTEZİ VE KARAKTERIZASYONU}

\author{
Ecevit, Safiye Tuba \\ Yüksek Lisans, Polimer Bilimi ve Teknolojisi Bölümü \\ Tez Yöneticisi: Prof. Dr. Leyla Aras \\ Ortak Tez Yöneticisi: Prof. Dr. Teoman Tinçer
}

March 2004, 44 sayfa

Polypropilen yüzeyinin sülfonlanması üzerindeki bu araştırma, yüzey tasarımı ve yüzeyin fonksiyonelleşmesi ile olan ilgisi bakımından oldukça önemlidir.

$\mathrm{Bu}$ amaç için, polipropilen film yüzeylerinin çeşitli sıcaklıklarda ve farklı süreler için sülfonlanması derişik sülfürik asit kullanılarak yapılmıştır. Sülfonlanmanın etkisiyle polipropilen yüzeyleri üzerinde oluşan fiziksel ve kimyasal değişiklikler, değme açısı ölçümü, mekanik analiz, UV-Vis. spektroskopi, DSC ve SEM ile tayin edilmiştir.

Örneklerin yüzeylerinin polarlık ve 1slanabilirlik özellikleri değme açıs1 ölçümleriyle değerlendirilmiştir. Düşük sıcaklık ve süredeki sulfonlanmanın her iki 
özelliği de iyileştirdiği görülmüştür. Ancak yüksek sıcaklık ve süredeki sülfonlanma, polimerin bozunmasıyla birlikte bölgesel kopmalara neden olmuştur.

Yüksek sıcaklık ve sürede sulfonlanan polipropilen filimlerdeki karbonlaşma ve bozunmadan dolayı oluşan, fark edilebilir renk değişikliği UV- Vis. Spektrumları ile desteklenmiştir.

Sülfonlanmış polipropilen filimlerin mekanik özellikleri araştırılmış ve sonuç olarak sülfonlanma işleminden sonra polipropilen filimlerin mekanik özellikleri, sülfonlanma sıcaklığı ve süresine bağlı olarak genel bir düşüş eğilimi göstermiştir. $\mathrm{Bu}$ düşüş yüksek sıcaklıktaki sülfonlanma için çok daha hızlı olmuştur.

Isıl özellikleri DSC ile tayin edilmiştir ve sülfonlanmış polipropilen örneklerinin, sülfonlanmaya bağlı olarak ayrı bir endotermik pik gösterdiği gözlenmiştir.

Sülfonlanmanın polypropilen yüzeylerindeki fiziksel etkileri SEM ile araştırılmış ve örneklerde polipropilen içindeki hava kabarcıklarının sulfonlanmanın etkisi sonucu patlamasıyla oluşan hekzagonal yapıda delikler görülmüştür. Ayrıca bu deliklerin etrafında lamel oluşumlar gözlemlenmiştir.

Anahtar Kelimeler: Polipropilen, Yüzey modifikasyonu, Yüzey Sülfonlanması, Polipropilen Yüzeyinin Sülfonlanması. 
To my family

and

To the memory of my brother A.Tuğrul Ecevit

vii 


\section{ACKNOWLEDGEMENTS}

I would likely express my special thanks to my supervisor Prof Dr Leyla Aras for her guidance and help throughout this research. I also wish to express my appreciation to my co-supervisor Prof Dr Teoman Tinçer for his understanding.

I also would like to express my special thanks to Prof. Dr. Erdal Bayramlı for his guidance and continuous care in contact angle measurements.

I would like to thank to my lab-mates, Cemil Alkan, Arzu Büyükyağcı, Evrim Şen, Funda Çelebi, Özlem Akın and Ahu Dumanlı for their endless helps and friendships and Güralp Özkoç for his helps through the mechanical testing of my samples.

I thank to Esra Öztekin and Gözde Ersan for their belief in me and for their very special friendship

Finally, I would like to thank to my family for their never ending encouragement, support and love. 


\section{TABLE OF CONTENTS}

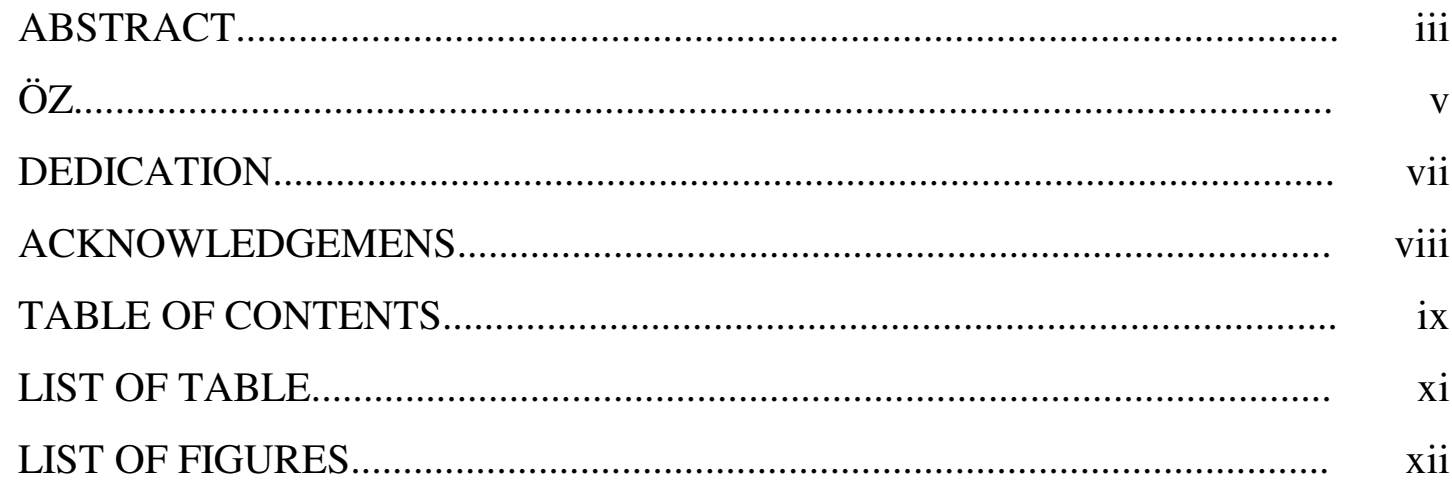

\section{CHAPTER}

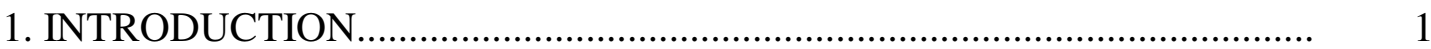

1.1 Polymer Surface Modification.................................................... 1

1.2 Polypropylene............................................................................ 3

1.3 Surface sulfonation of PP ...................................... 6

1.3.1 Mechanism of sulfonation of PP........................................... 6

1.4 Methods of Characterization of Surface modified PP..................... 8

1.4.1 Surface Tension and Contact Angle Measurements............... 8

1.4.2. The Wilhelmy Plate Method............................ 10

1.5 Mechanical Measurements............................................................. 13

1.6 The Aim of the Study........................................ 15 
2. EXPERIMENTAL ................................................................. 16

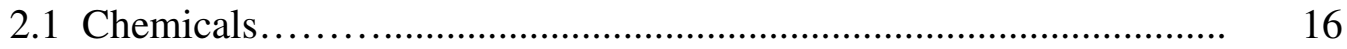

2.2 Instrumentation.................................................................... 16

2.3 Preparation of Samples.................................................................. 17

2.3.1 Preparation of PP Films ………………………………........ 17

2.3.2 Sulfonation of PP Films........................................................... 17

2.3.3 Contact Angle Measurement.................................................... 18

2.3.4 Preparation of Samples for Mechanical Testing.................. 19

3. RESULTS AND DISCUSSION ...................................... 20

3.1 Contact Angle Measurement Results....................................................... 20

3.2 UV-Vis. Analysis Results................................................................. 25

3.3 Mechanical Analysis Results ......................................................... 28

3.4 Differential Scanning Calorimeter Results........................................... 31

3.5 Scanning Electron Microscopy Results........................................... 34

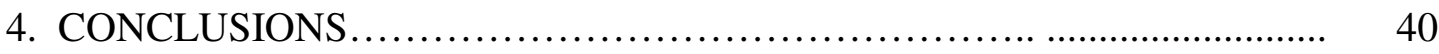

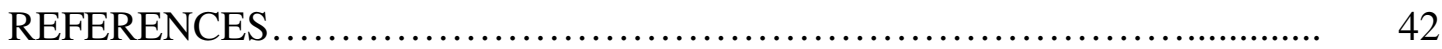




\section{LIST OF TABLES}

\section{TABLE}

2.1. Surface components of probe liquids used........................................ 18

3.1. The contact angle values made by the probe liquids on the PP 20

Films...............................................................

3.2. Harmonic Mean Results.................................................................. 21

3.3. Geometric Mean Results......................................................... 21

3.4. Water contact angle values on PP Films...................................... 23

3.5. Stress at yield and break values of untreated and treated PP films .... 29 


\section{LIST OF FIGURES}

FIGURE

1.1a Polypropylene monomer....................................... 4

1.1b Isotactic, syndiotactic and atactic form of polypropylene.............. 4

1.2 The $3_{1}$ helical conformation of isotactic polypropylene in crystalline st. 5

$1.3 \quad$ Equilibrium contact angle ........................................ 8

$1.4 \quad$ A set up for Wilhelmy method.................................... 11

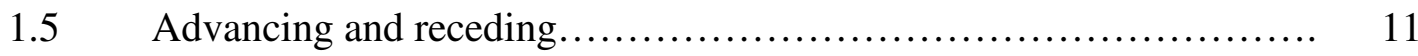

1.6 The balance of the forces for depth of immersion.................... 12

$1.7 \quad$ Idealized stress strain curve........................................ 14

3.1 Contact angle values of water on treated PP film vs sulfonation time 24

3.2 The absorption spectrum of untreated PP film ...................... 25

3.3 The absorption spectrum of PP film treated at $120^{\circ} \mathrm{C}$ for 2 hours........ 26

3.4 The absorption spectrum of PP film treated at $120^{\circ} \mathrm{C}$ for 3 hours........ 26

3.5 The absorption spectrum of PP film treated at $120^{\circ} \mathrm{C}$ for 4 hours........ 27

3.6 The absorption spectrum of PP film treated at $120^{\circ} \mathrm{C}$ for 5 hours........ 27

3.7 Stress at break values vs treatment time at $10^{\circ} \mathrm{C}, 25^{\circ} \mathrm{C}$, and $120^{\circ} \mathrm{C} \ldots \ldots \quad 30$

3.8 Stress at yield values vs treatment time at $10^{\circ} \mathrm{C}, 25^{\circ} \mathrm{C}$, and $120^{\circ} \mathrm{C} \ldots \ldots . \quad 30$

$3.9 \quad$ DSC thermogram of untreated PP ............................... 31

3.10 DSC thermogram of PP film treated at $10^{\circ} \mathrm{C}$ for 1 hour................ 32

3.11 DSC thermogram of PP film treated at $25^{\circ} \mathrm{C}$ for 1 hour................ 32

3.12 DSC thermogram of PP film treated at $120^{\circ} \mathrm{C}$ for 1 hour............... 33

3.13 The SEM photograph of PP film sulfonated at $10^{\circ} \mathrm{C}$ for $30 \mathrm{~min} \ldots \ldots \ldots . .34$

3.14 The SEM photograph of PP film sulfonated at $10^{\circ} \mathrm{C}$ for $3 \mathrm{hrs}$. 35 
3.15 The SEM photograph of PP film sulfonated at $25^{\circ} \mathrm{C}$ for $3 \mathrm{hrs} \ldots \ldots \ldots \ldots . . .35$

3.16 The SEM photograph of PP film sulfonated at $120^{\circ} \mathrm{C}$ for $1 \mathrm{hr} \ldots \ldots \ldots . .36$

3.17 The SEM photograph of PP film sulfonated at $10^{\circ} \mathrm{C}$ for $2 \mathrm{hrs} \ldots \ldots \ldots \ldots . . . .36$

3.18 The SEM photograph of PP film sulfonated at $25^{\circ} \mathrm{C}$ for $30 \mathrm{~min} . \ldots \ldots . . .37$

3.19 The SEM photograph of PP film sulfonated at $120^{\circ} \mathrm{C}$ for $3 \mathrm{hrs} . \ldots \ldots \ldots . .37$

3.20 The SEM photograph of PP film sulfonated at $120^{\circ} \mathrm{C}$ for $4 \mathrm{hrs} \ldots \ldots \ldots . . .38$

3.21 The SEM photograph of PP film sulfonated at $120^{\circ} \mathrm{C}$ for $5 \mathrm{hrs} \ldots \ldots \ldots . . .38$ 
xiv 
xv 
xvi 
xvii 


\section{xviii}




\section{CHAPTER 1}

\section{INTRODUCTION}

\subsection{Polymer Surface Modification}

Polymers have been applied successfully in the fields such as; adhesion, biomaterials, protective coating, friction and wear, composites, microelectronic devices, thin-film technology. In general, special surface properties such as chemical composition, hydrophilicity, roughness, crystallinity, conductivity, lubricity, and crosslinking density are required for the success of these applications. Polymers very often do not possess the surface properties needed for these applications. However, they have excellent bulk physical and chemical properties and are easy to process. For these reasons, surface modification techniques can transform these inexpensive materials into valuable finished products have become an important part of the plastics industry. In recent years, many advances have been made in developing surface treatments to alter the chemical and physical properties of polymer surface without affecting bulk properties. As reported in many papers, and review articles [1-9], these treatments have been applied to achieve the following purposes:

- produce special functional groups at the surface

- increase surface energy

- increase hydrophobicity or hydrophilicity

- introduce surface cross-linking

- introduce chemical inertness

- remove weak boundary layers or contaminants 
- modify surface morphology

- increase surface electrical conductivity

- increase surface lubricity

The technologies used to alter polymer surfaces are[10]:

Flame Treatment: It is based on oxidation of polymer surface for improved bondability with an adhesive or for improved printability and mark permanence. This is provided by high flame temparature $\left(1000-2000{ }^{\circ} \mathrm{C}\right.$ ) or reactions with many excited species in the flame. The equipment is very simple and portable (a burner and a fuel tank)

Corona Discharge: In the system, a plasma is produced when air is ionized by a high electric field. The atmospheric pressure plasma, which is called a corona discharge causes various chemical and physical changes on polymer surface for improved bondability and printability

Plasma Treatment: Water and different types of gas such as argon, oxygen, nitrogen, fluorine and carbondioxide can produce unique surface properties by various applications.

Chemical Treatment: In this technique chemical etchants are used to convert smooth hydrophobic polymer surface to rough hydrophilic surfaces by dissolution of amorphous regions and surface oxidation. By this, surface topographies and functionality can change and surface will be platable or bondable.

Ion Beam Modification: In this method a texture is produced on polymer surface by different ion-beam bombardment. By this, different chemical reaction (reduction, oxidation, cross-linking, ion implantation, loss of heteroatom and loss of aromaticity ) occurs on the surface. 
Radiation Grafting: In this method surface properties of the polymer is tailored through the choice of different monomer. The common radiation sources are high energy electrons, $\boldsymbol{\gamma}$ radiation and UV- Visible lights. Grafting is performed by irradiating the polymer in the presence of a solvent containing a monomer.

Plasma Polymerization: In this method, polymer films with unique chemical and physical properties are produced by plasma polymerization.

Polymer Blends and Block Copolymer: Multiphase polymers, including block and graft copolymers as well as blend exhibit distinct chemical and physical properties at the surface.

Photochemical Treatment: In this method, surface modification is done by UV and IR lasers for some specific applications.

Metal Deposition: Many desirable surface properties, such as electrical conductivity and optical characteristics can be achieved by metal coatings. The metal coating on polymer surface can be done two major techniques, vacum deposition and electroless plating.

\subsection{Polypropylene}

Isotactic polypropylene was first produced by $\mathrm{G}$ Natta, following the work of $\mathrm{K}$. Ziegler, by the polymerization of propylene monomer in 1954. The macromolecule of PP contains 10,000 to 20,000 monomer units. The steric arrangement of the methyl groups give stereochemistry of the PP chain. (Figure 1.1.a. and 1.1.b.) [11-12] 


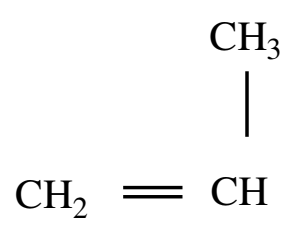

Figure 1. 1.a. Propylene monomer
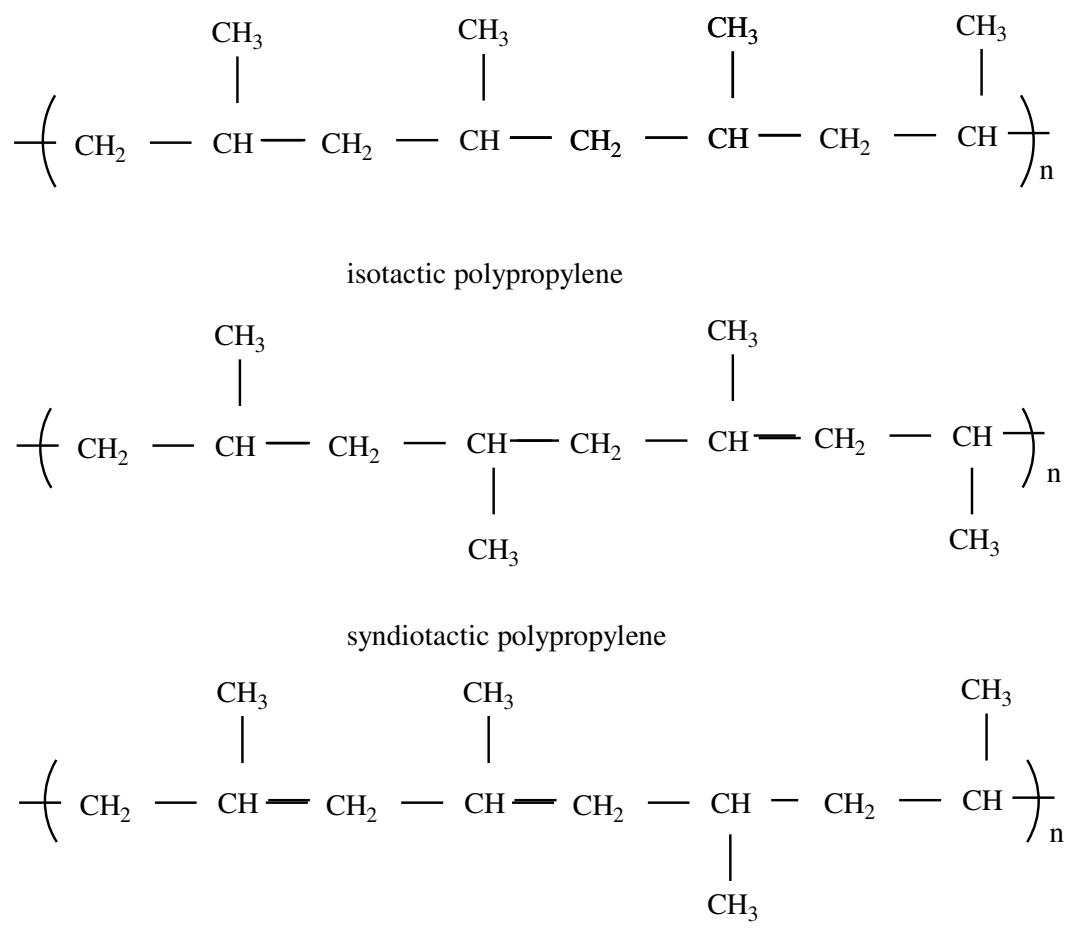

atactic polypropylene

Figure 1. 1.b. PP molecule in isotactic, syndiotactic, and atactic forms [11].

The crystallizability of the chain is a critical factor governing the resultant morphology. The degree of crystallinity of homopolymer PP is governed primarily by the tacticity of the chain. As the tacticity along the polymer chain is reduced, the crystallinity decreases. In the extreme case, the crystallinity of atactic PP is zero [13].

The wide use of isotactic polypropylene as a practical solid material is undoubtedly due to its high crystallinity. It shows polymorphism due to crystallization 
into a variety of modification of different orders. The crystal structures of isotactic polypropylene have been studied extensively and were recognized to be influenced by various conditions of polymer processing, such as, heating temperature to melt, and cooling rate from the melt to the solid state [14]. A rapid quenching gives a tough clear product since it suppresses the formation of crystals, while annealing or slow cooling of the product leads rather brittle and hazy product. Increased crystallinity increases hardness, modulus, strength, abrasion, wear resistance, creep resistance, barrier properties, shrinkage and density. Low crystallinity offer the advantages of good processibility, and better transparency [11].

In the crystalline state, isotactic polypropylene prefers an alternate trans and gauche (TGTGTG....) conformation with respect to main chain carbon atom. This conformation results in a three fold $\left(3_{1}\right)$ symmetry of helix with a chain repetition of $6.50 \AA$ as shown in Figure 1.2. [14].
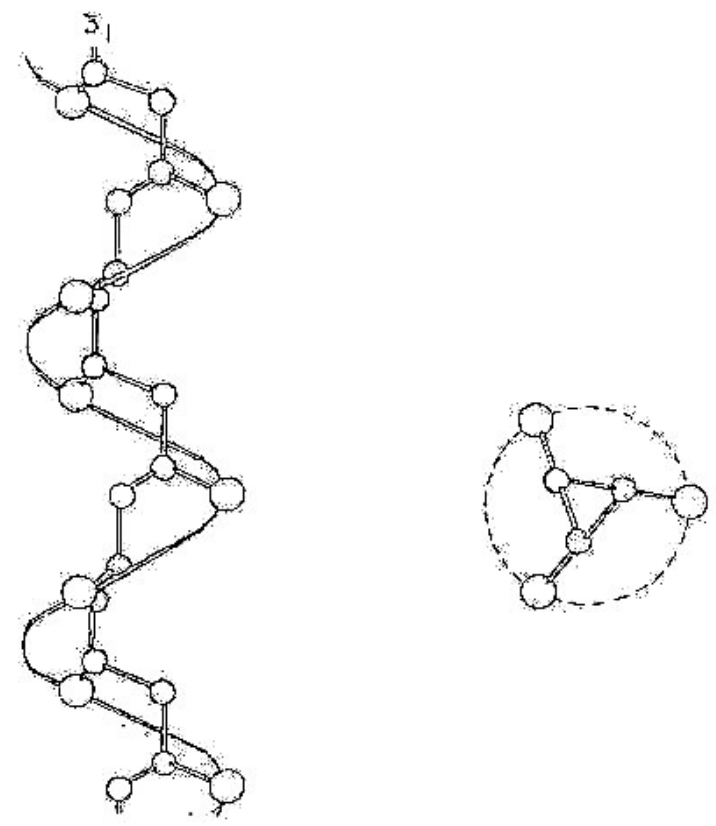

Figure 1.2. The $3_{1}$ helical conformation of isotactic PP in crystalline state [12]. 


\subsection{Surface Sulfonation of Polypropylene}

The poor adhesion properties of polypropylene necessitate that a surface treatment to functionalize and alter the physico-chemical properties be performed prior to bonding [15]. If the surface of polypropylene can be changed from a hydrophobic to a hydrophilic state, the high insulating character and low density should make it a desirable material for many specific applications [16]. In general, surface treatment methods incorporate polar groups onto the material surface, thereby improving the wettability and increasing the chemical reactivity between polymer and adhesives.

One chemical surface treatment utilizes the reaction products of polymer treated with sulfur trioxide $\left(\mathrm{SO}_{3}\right)$ to increase the wettability and adhesion[17]. Sulfur trioxide is highly reactive, but inexpensive chemical, obtainable either in liquid or gas form.

Liquid sulfonation of polymers using aqueous concentrated sulfuric acid [18] or fuming sulfuric acid (oleum), as well as solutions of $\mathrm{SO}_{3}$ in inert liquid solvent $[15,19]$ have been investigated. Several research groups also have investigated the use of gas phase sulfonation [20].

\subsubsection{Mechanism of Sulfonation of Polypropylene}

In the sulfonation reaction, a large positive charge on the $S$ atom compensated by the charge on the $\mathrm{O}$ atoms indicates that $\mathrm{S}$ atom acts as an electrophilic center. On the other hand, all the $\mathrm{C}$ atoms have negative charges. Then, the sulfonation of PP can be presumed via electrophilic addition of $\mathrm{SO}_{3}$ in a similar manner as in aromatic compounds. A probable reaction scheme is expressed by the Eq 1.1. 


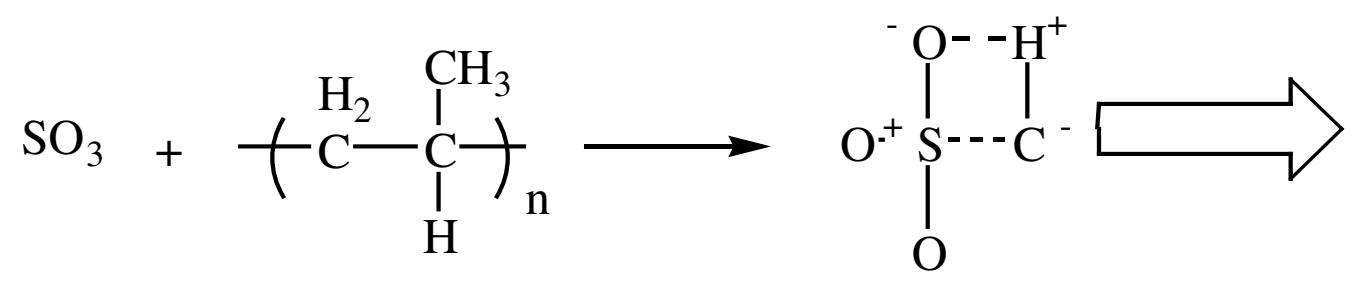

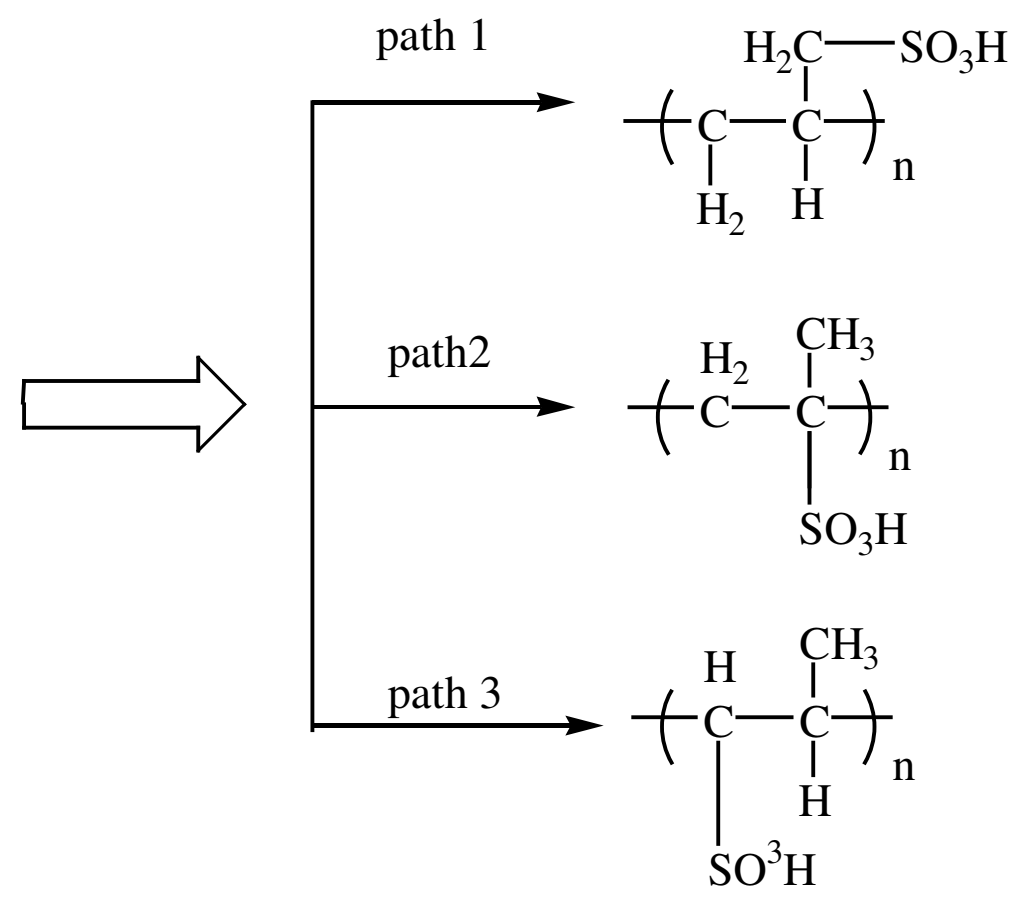

Equation 1.1 The Reaction Scheme of Sulfonation of Polypropylene [16].

The researchers working on this subject [16] conclude that, path 2 and 3 accompanied by the remarkable conformational change should have a much greater activation energy compared to path 1 which results in the selectivity of the reaction site in the sulfonation of PP. 


\subsection{Methods of Characterization of Surface Modified PP}

\subsubsection{Surface Tension and Contact Angle Measurement}

Contact angle measurements have been used extensively in studying changes in polymer surface composition caused by various surface treatment tecniques [21-25], aging characteristics of modified surfaces, migration of hydrophobic and hydrophilic functional groups in aqueous and nonaqueous environments [26-30]. Contact angle is sensitive to the chemical composition of the top molecular layer and it is relatively simple, inexpensive, and popular technique for characterizing the polymer surface [10].
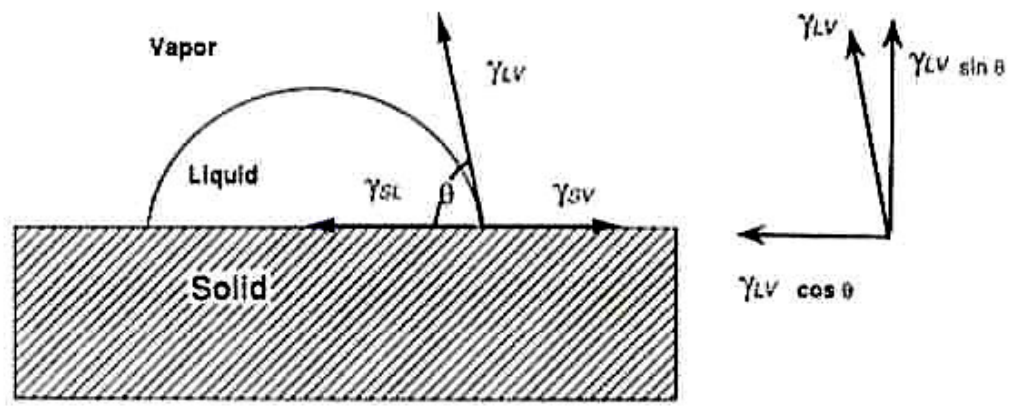

Figure 1. 3. Equilibrium contact angle [10].

When a drop of a liquid rests on a solid surface, it makes a definite angle of contact between the liquid and the solid phases, called contact angle. The contact angle as shown Figure 1.3, is governed by the force balance at the three phase boundary and it is defined by Young's equation. (Equation 1.2.)

$$
\gamma_{\mathrm{s}}=\gamma_{\mathrm{sl}}+\gamma_{\mathrm{lv}} \cos \theta
$$


Where $\gamma_{s}$ is the surface energy of the solid, $\gamma_{s l}$ is the interfacial tension between the solid and the liquid, and $\gamma_{1 \mathrm{v}}$ is the interfacial tension between the liquid and the vapour (surface tension of the liquid).

Many different methods have been proposed to evaluate $\gamma_{\mathrm{s}}$ using values of contact angles formed by drops of different liquids with known surface tensions [31].

It was proposed by $\mathrm{Wu}[32]$, and it is widely accepted that intermolecular energy between two materials results from the summation of a dispersion component and a polar component. Since the surface tension is proportional to the intermolecular energy, the surface tension $\gamma$ itself can be considered as a sum of a dispersion component $\gamma^{\mathrm{d}}$ and a polar component $\gamma^{\mathrm{p}}$.

The interfacial tension between a liquid and a solid polymer can be evaluated by harmonic mean equation (Equation 1. 3.), as follows:

$$
\gamma_{\mathrm{sl}}=\gamma_{\mathrm{s}}+\gamma_{\mathrm{lv}}-4\left(\frac{\gamma_{\mathrm{lv}}{ }^{\mathrm{d}} \gamma_{\mathrm{s}}^{\mathrm{d}}}{\gamma_{\mathrm{lv}}{ }^{\mathrm{d}}+\gamma_{\mathrm{s}}{ }^{\mathrm{d}}}+\frac{\gamma_{\mathrm{lv}}^{\mathrm{p}} \gamma_{\mathrm{s}}^{\mathrm{p}}}{\gamma_{\mathrm{lv}}^{\mathrm{p}}+\gamma_{\mathrm{s}}^{\mathrm{p}}}\right)
$$

or geometric mean equation (Equation 1.4.), as follows:

$$
\gamma_{\mathrm{sl}}=\gamma_{\mathrm{s}}+\gamma_{\mathrm{lv}}-2\left[\left(\gamma_{\mathrm{lv}}^{\mathrm{d}} \gamma_{\mathrm{s}}^{\mathrm{d}}\right)^{0.5}+\left(\gamma_{\mathrm{lv}}^{\mathrm{p}} \gamma_{\mathrm{s}}^{\mathrm{p}}\right)^{0,5}\right]
$$

Where $\gamma_{\mathrm{s}}$ is the surface energy of the polymer, $\gamma_{\mathrm{sl}}$ is the interfacial tension between the liquid and the polymer, and $\gamma_{\mathrm{lv}}$ is the surface tension of the liquid, $\gamma_{\mathrm{s}}^{\mathrm{d}}$ and $\gamma_{\mathrm{s}}^{\mathrm{p}}$ are the dispersion and polar components of the surface energy of the polymer, and $\gamma_{1 \mathrm{v}}{ }^{\mathrm{d}}$ and $\gamma_{\mathrm{lv}}{ }^{\mathrm{p}}$ 
are the dispersion and polar components of the surface tension of the liquid, respectively.

Using Eq. 1.2, Eq.1.3. and 1.4. transform into Eq 1.5. and 1.6, respectively.

$$
\begin{aligned}
& \gamma_{l v}(1+\cos \theta)=4\left(\frac{\gamma_{l v}{ }^{d} \gamma_{s}^{d}}{\gamma_{l v}{ }^{d}+\gamma_{s}{ }^{d}}+\frac{\gamma_{l v}{ }^{p} \gamma_{s}^{p}}{\gamma_{l v}^{p}+\gamma_{s}^{p}}\right) \\
& \gamma_{\text {lv }}(1+\cos \theta)=2\left[\left(\gamma_{\text {lv }}{ }^{\mathrm{d}} \gamma_{\mathrm{s}}^{\mathrm{d}}\right)^{0.5}+\left(\gamma_{\mathrm{lv}}^{\mathrm{p}} \gamma_{\mathrm{s}}^{\mathrm{p}}\right)^{0,5}\right]
\end{aligned}
$$

If the contact angles made by two liquids of known $\gamma^{\mathrm{d}}$ and $\gamma^{\mathrm{p}}$ are measured, it is possible to solve equation 1.5. (harmonic mean ) or 1.6. (geometric mean) and infer $\gamma_{\mathrm{s}}{ }^{\mathrm{d}}$ and $\gamma_{\mathrm{s}}^{\mathrm{p}}$ for the solid [31].

\subsubsection{Wilhemy Plate Method}

There are several methods for measuring the contact angle. The Wilhelmy plate method is the most widely used method since it is a simple and the most accurate tecnique. The system comprises an electrobalance, which is used to measure the wetting force at the solid-liquid interface as a function of immersion depth, and a stage, which can be moved up and down at controlled speeds as shown in Figure 1. 4. 


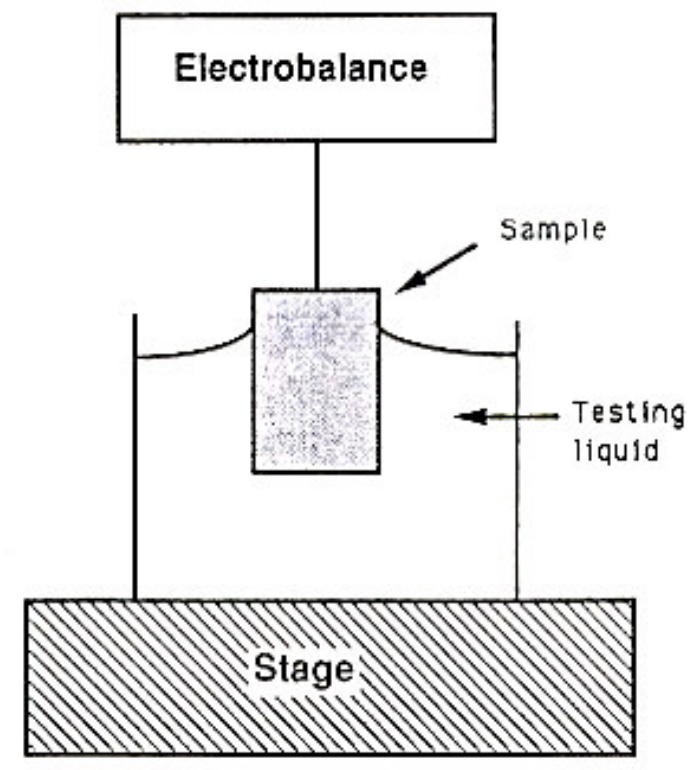

Figure 1. 4. A set up for Wilhelmy method [10]

The solid sample (a flat plate or a single fiber )is held in position by the electrobalance. The set up can be used to measure both static and (advancing or receding) and dynamic contact angle. Static advancing and receding (Figure 1.5.) contact angles are obtained by immersing and withdrawing the plate, respectively. Measurements are made when the plate is stationary. Dynamic contact angles, which are rate dependent, are measured when the plate is moving.

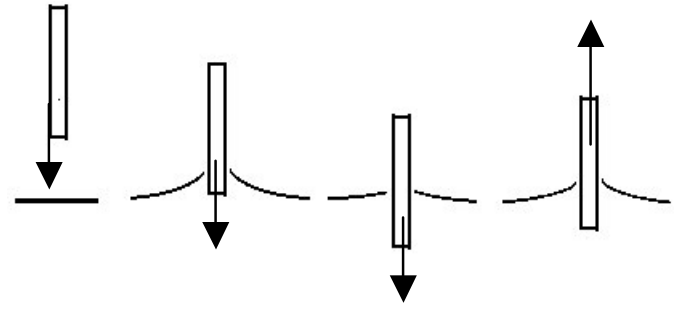

Figure 1.5. Advancing and Receding [33]. 


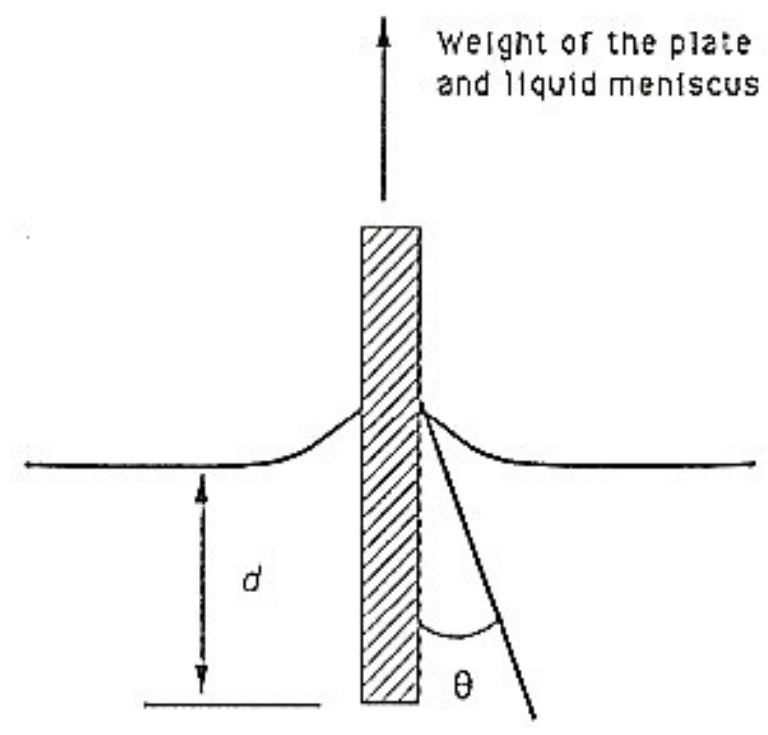

Figure 1.6. The balance of the forces for depth of immersion $d$ [10].

The force acting on the plate, which is hung vertically at an immersion depth $d$ (Figure 1.6.), is

$$
\mathrm{F}=p \gamma_{\mathrm{lv}} \cos \theta-\Delta \rho \mathrm{g} \mathrm{A} d
$$

Where $\mathrm{F}$ is the force, $p$ is the plate perimeter, $\gamma_{1 \mathrm{v}}$ is the surface of the wetting liquid, $\theta$ is the contact angle, $\Delta \rho$ is the difference in densities of the liquid and the solid, and $\mathrm{g}$ is the gravitational acceleration. The term $p \gamma_{\mathrm{lv}} \cos \theta$ is the force exerted on the plate and the term $\Delta \rho \mathrm{g} \mathrm{A} d$ is the buoyancy force. For static contact angle determination, buoyancy force can be eliminated by extrapolating the graph back to zero depth of immersion. The remaining component force is the wetting force which is defined as[10]:

$$
\text { Wetting force }=p \gamma_{1 \mathrm{v}} \cos \theta
$$




\subsection{Mechanical Measurements}

There are a number of fundamental techniques used to characterize the mechanical properties of polymers, including tensile, flexural, tear strength, fatigue, impact and hardness tests.

The degree to which a material will strain depends on the magnitude of the imposed stress. This stress $(\sigma)$ is defined as the load $(F)$ per unit area (A), given as follows:

$$
\sigma=\mathrm{F} / \mathrm{A}
$$

There are three basic types of stress measurements- tensile stress is the resistance of a material to strecthing forces, compressive stress is the resistance of a material to 'squashing' forces, while shear stress is the resistance of a material to 'push-pull' forces.

The strain $(\varepsilon)$ is the amount of deformation per unit length of the material due to the applied load, and is given as follows:

$$
\varepsilon=\left(l_{i}-l_{0}\right) / l_{0}=\Delta 1 / l_{0}
$$

where $l_{0}$ is the original length of the sample before any load is applied, $l_{i}$ is the instantaneous length, and $\Delta 1$ is the amount of elongation.

Deformation where the stress and strain are proportional is called elastic deformation. In such a case, a plot of stress against strain produces a linear graph. The slope of such a plot provides the Young's modulus (also known as the modulus of elasticity or the tensile modulus) (E) of the material, which is also the proportionality constant. The modulus can be thought of as the 'stiffness' of a polymer. The parameter E 
can be evaluated from the slope of the linear elastic portion of a force-extension curve where:

$$
\mathrm{E}=(\text { slope } \mathrm{x} \text { gauge length }) /(\text { cross-sectional area })
$$

The data derived from stress-strain measurements on thermoplastics are important from a practical viewpoint, providing information on the modulus, the brittleness, and the ultimate and yield strengths of the polymer. By subjecting the specimen to a tensile force applied at a uniform rate and measuring the resulting deformation, a curve of the type shown in Figure 1.7 can be constructed [34].

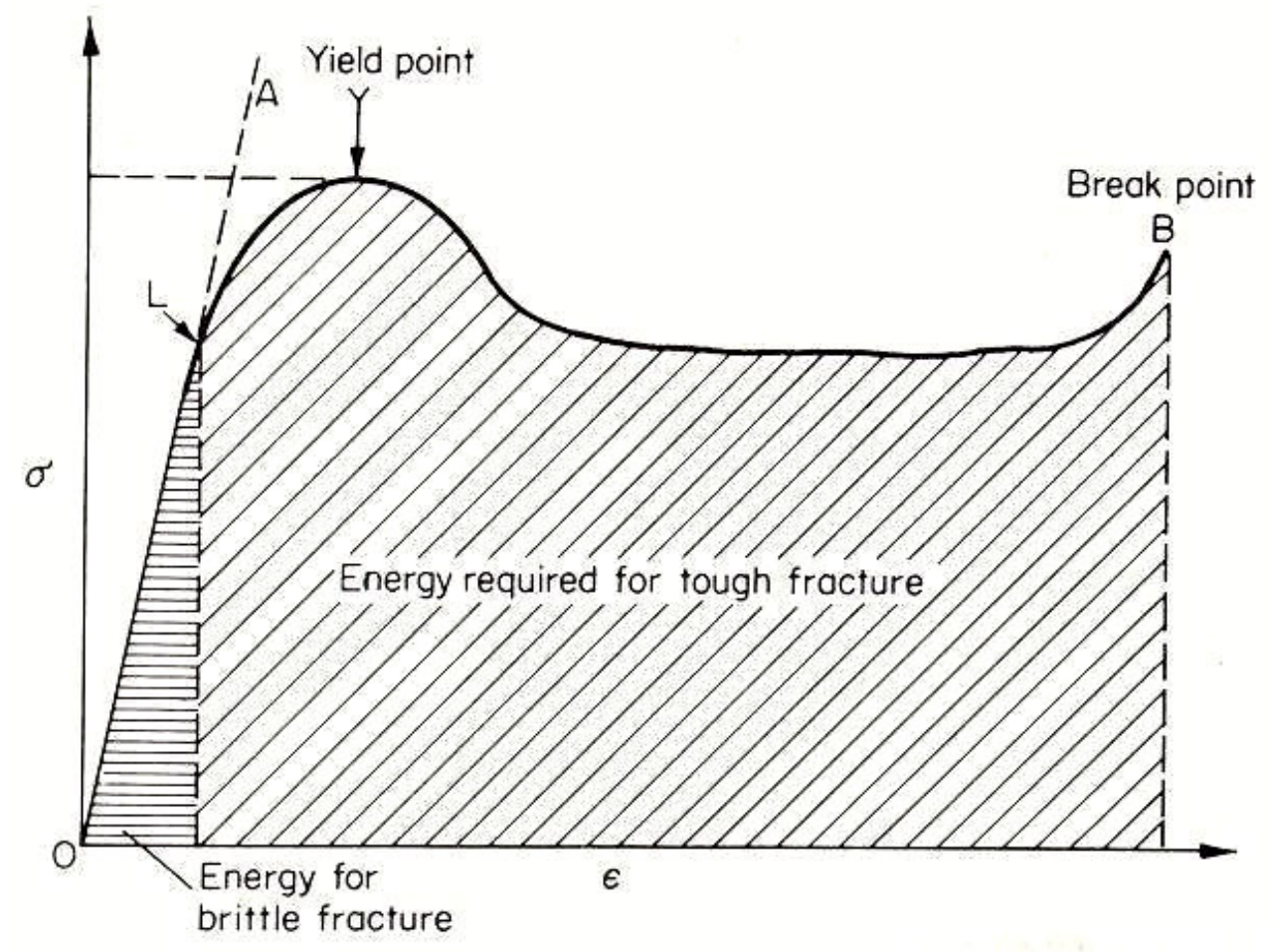

Figure 1.7. Idealized stress-strain curve. The slope of line OA is a measure of the true modulus [34]. 


\subsection{The Aim of The Study}

The major objective of the present research is to change the surface properties of polypropylene films by converting the hydrophobic character of the polypropylene surface to hydrophilic character by some specific functionalization.

This research includes the liquid-phase sulfonation of polypropylene films performed at various temperatures and for different time periods to find out the optimum condition for surface sulfonation, and characterization of the surface properties of the treated polypropylene films. 


\section{CHAPTER 2}

\section{EXPERIMENTAL}

\subsection{Chemicals}

2.1.1. Isotactic Polypropylene, iPP MH 418 is provided by Petkim, Turkey.

2.1.2. Sulfuric Acid, $\mathrm{H}_{2} \mathrm{SO}_{4}$ is reagent grade and used to sulfonation of polypropylene films.

2.1.3. n-Dodecane, Diiodomethane and Formamide are Merck and Aldrich grade and used as probe liquid for contact angle measurements.

\subsection{Instrumentation}

2.2.1. Microbalance M25D: Contact angles were measured tensiometrically with a Sartorious Microbalance M25D in conjuction with an Oriel motor-driven stage that has a vertical displacement capability of $10 \mathrm{~mm}$. The digital signals from the microbalance were recorded as their analog counterparts with a Linseis LY 140 type, $\mathrm{X} / \mathrm{Y}$ recorder.

2.2.2. UV-Visible Recording Spectrometer: Absorption spectrums of PP films were taken from UV-Vis 160 model spectrometer. 
2.2.3. Mechanical Testing: Lloyd Instrument LS 5000 was used to perform mechanical testing with a crosshead speed of $5 \mathrm{~mm} / \mathrm{min}$.

2.2.4. Differential Scanning Calorimetry (DSC): The thermal analysis of the samples were made by using Perkin Elmer (DSC) Differential Scanning Calorimeter. Samples were scanned in the temperature range of $25-250{ }^{\circ} \mathrm{C}$ at 10 ${ }^{\circ} \mathrm{C} / \mathrm{min}$. They were cooled $\left(10{ }^{\circ} \mathrm{C} / \mathrm{min}\right)$ and scanned for the second time.

2.2.5. Scanning Electron Microscopy (SEM): JSM-6400 Scanning Electron Microscope of Noran Instruments Inc. in Metallurgical and Material Science Engineering Department was used. Because of unconsiderable conductivity of blends, samples to be analyzed by SEM were covered by gold and made conductive. Then analysis of appearance could be performed.

\subsection{Preparation of Samples}

\subsubsection{Preparation of PP Films}

Thin films having the thickness of $0.20-0.30 \mathrm{~mm}$ were prepared by compression moulding at $200 \pm 10{ }^{\circ} \mathrm{C}$ for 7 minutes and they were cooled fastly.

\subsubsection{Sulfonation of Polypropylene Films}

The polypropylene films were immersed in concentrated $\mathrm{H}_{2} \mathrm{SO}_{4}$ solution and kept at a given temperature $\left(10,25,120{ }^{\circ} \mathrm{C}\right.$ ) for various times (30 minutes, 1 hour, 2 hours and 3 hours). They were rinsed in four steps by aqueous solutions of $\mathrm{H}_{2} \mathrm{SO}_{4}$ with volume percents of 70, 50 and $37.5 \%$ in this order for 10 minutes each and finally with pure water and dried at $50{ }^{\circ} \mathrm{C}$ in vacuum oven. 


\subsubsection{Contact Angle Measurement}

Contact angles were measured tensiometrically with a Sartorious Microbalance M25D in conjuction with an Oriel motor-driven stage that has a vertical displacement capability of $10 \mathrm{~mm}$. In the case of PP films, a single film specimen having the size of $1 \mathrm{~cm}$ width to $2 \mathrm{~cm}$ length was prepared first, by taping with a piece of adhesive tape with $1 \mathrm{~cm}$ of the film exposed. The specimen then suspended from the balance by a steel wire hook through a hole drilled in the tape. In all experiments a stage velocity of $1 \mu \mathrm{m} / \mathrm{s}$ was used to bring the film in contact with the liquid. The force on the film was measured as the container was raised to obtain an advancing contact angle. Each contact angle measurement was repeated two times.

In order to obtain reliable values of surface energy using the harmonic and geometric mean equations, a pair of polar (formamide) and nonpolar (diiodomethane) liquids were used as probe liquid. After each experiment, the wetted part of the films was cleaned by washing with acetone and for each film the perimeters were determined by measuring the wetting force using n-dodecane, which is completely wetting liquid that is assumed to make a zero contact angle with PP films. The surface tension of the liquids used are presented in Table 2.1.[21]

Table 2.1. Surface components of probe liquids used in this work (values are in $\mathrm{mN} / \mathrm{m}$ )

\begin{tabular}{|lccc|}
\hline Liquids & $\boldsymbol{\gamma}$ & $\boldsymbol{\gamma}^{\mathbf{d}}$ & $\boldsymbol{\gamma}^{\mathbf{p}}$ \\
\hline Formamide & 58.20 & 39.50 & 18.70 \\
Diiodomethane & 50.80 & 50.80 & 0.00 \\
\hline
\end{tabular}




\subsubsection{Preparation of the Samples for Mechanical Testing}

Tensile tests were done with a crosshead speed of $5 \mathrm{~mm} / \mathrm{min}$ by using Lloyd LS 5000 Instrument. The specimens were in the form of thin films (gouge-length = $30 \mathrm{~mm}$, thickness $=0.25 \pm 0,05 \mathrm{~mm}$ and width $=3.00 \pm 0,2 \mathrm{~mm})$ prepared by compression moulding machine. 


\section{CHAPTER 3}

\section{RESULTS AND DISCUSSION}

\subsection{Contact Angle Measurements Results}

In order to determine the surface energies of PP films, characterization was done by wetting experiment in which the Wilhelmy Balance Method was used. In this method, a solid that has vertical surfaces is partially immersed into the probe liquid, due to a capillary effect, the liquid will either rise or be depressed along the vertical wall, thus exerting a force on the solid. According to Eq.1.8., calculated contact angle values formed by diiodomethane and formamide are given in Table 3.1.

Table 3.1. The contact angle values made by the probe liquids on the PP films

\begin{tabular}{|l|c|c|}
\hline Samples & Formamide $\left(^{\circ}\right)$ & Diiodomethane $\left(^{\circ}\right)$ \\
\hline Pure PP & 79.42 & 53.65 \\
\hline at $25^{\circ} \mathrm{C}$ for 30 minutes & 73.98 & 56.32 \\
at $25{ }^{\circ} \mathrm{C}$ for 1 hour & 76.93 & 58.46 \\
at $25^{\circ} \mathrm{C}$ for 2 hours & 78.34 & 59.34 \\
\hline at $10^{\circ} \mathrm{C}$ for 30 minutes & 75.15 & 58.19 \\
at $10{ }^{\circ} \mathrm{C}$ for 1 hour & 77.22 & 60.20 \\
at $10{ }^{\circ} \mathrm{C}$ for 2 hours & 76.23 & 61.00 \\
\hline
\end{tabular}


The experimental values of the contact angles were used to calculate the surface energy componets ( dispersion, $\gamma^{\mathrm{d}}$ and polar, $\gamma^{\mathrm{p}}$ ) of PP film and sulfonated PP films treated at $10{ }^{\circ} \mathrm{C}$ and $25^{\circ} \mathrm{C}$, for 30 minutes, 1 hour and 2 hours by Eq. 1.5 and 1.6. The Harmonic and Geometric Mean results are given in Table 3.2 and 3.3.respectively.

Table 3.2. Harmonic Mean Results

\begin{tabular}{|l|c|c|c|}
\hline Samples & $\boldsymbol{\gamma}^{\mathbf{d}}$ & $\boldsymbol{\gamma}^{\mathbf{p}}$ & $\boldsymbol{\gamma}$ \\
\hline Pure PP & 33.0 & 0.0 & 33.0 \\
\hline at $25^{\circ} \mathrm{C}$ for 30 minutes & 32.29 & 0.83 & 33.12 \\
at $25^{\circ} \mathrm{C}$ for 1 hour & 31.23 & 0.40 & 31.63 \\
at $25^{\circ} \mathrm{C}$ for 2 hours & 30.80 & 0.10 & 30.90 \\
\hline at $10^{\circ} \mathrm{C}$ for 30 minutes & 31.37 & 0.83 & 32.20 \\
at $10^{\circ} \mathrm{C}$ for 1 hour & 30.37 & 0.61 & 30.98 \\
at $10^{\circ} \mathrm{C}$ for 2 hours & 29.98 & 1.02 & 31.00 \\
\hline
\end{tabular}

Table 3.3. Geometric Mean Results

\begin{tabular}{|l|c|c|c|}
\hline Samples & $\gamma^{\mathbf{d}}$ & $\gamma^{\mathbf{p}}$ & $\gamma$ \\
\hline Pure PP & 32.21 & 0.06 & 32.27 \\
\hline at $25{ }^{\circ} \mathrm{C}$ for 30 minutes & 30.69 & 0.28 & 30.97 \\
at $25{ }^{\circ} \mathrm{C}$ for 1 hour & 29.46 & 0.13 & 29.59 \\
at $25^{\circ} \mathrm{C}$ for 2 hours & 29.95 & 0.07 & 30.02 \\
\hline at $10{ }^{\circ} \mathrm{C}$ for 30minutes & 29.61 & 0.29 & 29.99 \\
at $10{ }^{\circ} \mathrm{C}$ for 1 hour & 28.46 & 0.21 & 28.67 \\
at $10{ }^{\circ} \mathrm{C}$ for 2 hours & 27.99 & 0.41 & 28.40 \\
\hline
\end{tabular}


At the end of sulfonation process of PP films, it should be expected that, the polarity of the PP surface increases as the $\mathrm{SO}_{3}$ groups bonded to the surface increases. It is also expected that, this increase in the amount of polar groups brings an increase in the value of polar component $\left(\gamma^{\mathrm{p}}\right)$ of the surface tension of the treated PP films compared to the untreated PP film.

According to the values at Table 3.2, when the polar component of the PP films are compared, it is seen that untreated PP film has the lowest value of $\gamma^{\mathrm{p}}$ as expected. Since treated PP film surfaces have $\mathrm{SO}_{3}$ groups bonded, the surface polarity increases and this fact is reflected by the increase in $\gamma^{\mathrm{p}}$ values for treated samples. At $25^{\circ} \mathrm{C}$, first treatment with $\mathrm{H}_{2} \mathrm{SO}_{4}$ for 30 min. caused a rise in $\gamma^{\mathrm{p}}$ from 0.00 to 0.83 . After 30 minutes, however, a decrease is observed in $\gamma^{\mathrm{p}}$ values of treated PP films for both 1 hour and 2 hours. Same trend, i.e. the decrease in $\gamma^{p}$ values after $30 \mathrm{~min}$., is observed with the Geometric results at Table 3.3. It shows that long treatment time period for the sulfonation process causes degradation of PP film surfaces. This degradation was observed as extensive carbonization on the surface with the time of sulfonation and increased temperature (see coming section). The result is consistent with literature [15, $16]$.

At $10{ }^{\circ} \mathrm{C}$, the same trend is observed for 30 minutes and 1 hour sulfonated PP films. For 2 hours however, an increase is observed in $\gamma^{\mathrm{p}}$ values obtained from both harmonic and geometric results. In this set we did not observed any extensive color change in PP surface i,e. a limit degradation if any.

As for $\gamma^{\mathrm{d}}$ values, both Tables 3.2. and 3.3. show that as the period and the temperature of sulfonation increase, $\gamma^{\mathrm{d}}$ values decrease and this most probably accounts for the degradation of the PP surfaces by concentrated $\mathrm{H}_{2} \mathrm{SO}_{4}$. Since $\gamma$ is the sum of the 
$\gamma^{\mathrm{p}}$ and $\gamma^{\mathrm{d}}$, it also reflects the effect of solvent polarity and shows the same variance as temperature and period of sulfonation changes.

In this work, water is also used as a probe liquid $(\gamma=72.75 \mathrm{mN} / \mathrm{m})$ to measure water contact angle and to find out the wettability of the sulfonated PP films treated at various conditions.

It is expected that, by sulfonation of the PP film, the surface can be changed from hydrophobic to hydrophilic state, and this should be reflected by an increase in the wettability and a decrease in water contact angle.

The advancing contact angle values of the PP film and the PP films treated at 10 ${ }^{\circ} \mathrm{C}$ and $25{ }^{\circ} \mathrm{C}$ for different time periods are summarized in Table 3.4. The plots of contact angle values of water on treated PP films versus sulfonation time are shown in Figure 3.1.

Table 3.4. Water contact angle values on PP films

\begin{tabular}{|l|c|}
\hline \multicolumn{1}{|c|}{ Sample } & $\begin{array}{c}\text { Water Contact Angle } \\
\left({ }^{\circ}\right)\end{array}$ \\
\hline PP & 71.89 \\
\hline at $10^{\circ} \mathrm{C}$ for 30 minutes & 72.99 \\
at $10^{\circ} \mathrm{C}$ for 1 hour & 67.72 \\
at $10^{\circ} \mathrm{C}$ for 2 hours & 72.63 \\
\hline at $25^{\circ} \mathrm{C}$ for 30 minutes & 72.2 \\
at $25^{\circ} \mathrm{C}$ for 1 hour & 71.03 \\
at $25^{\circ} \mathrm{C}$ for 2 hours & 75.28 \\
\hline
\end{tabular}




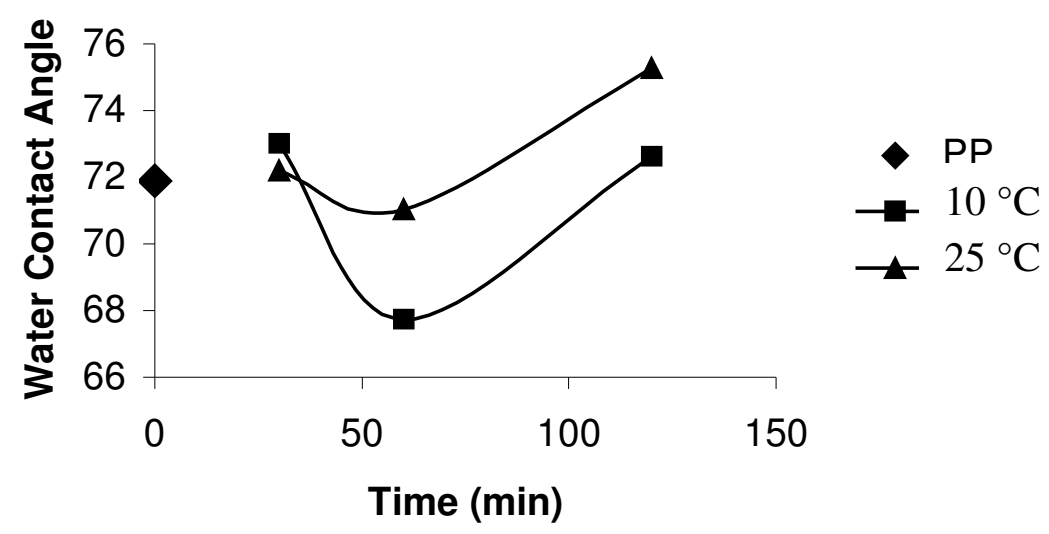

Figure 3.1. Contact angle values of water on treated PP films versus sulfonation time

For the 30 minutes treatments, the contact angle values of the films are close to that of untreated PP. After $30 \mathrm{~min}$, contact angle is reduced both at $10{ }^{\circ} \mathrm{C}$ and $25^{\circ} \mathrm{C}$. The rate of decrease of contact angle of water on the film treated at $25^{\circ} \mathrm{C}$ was higher than the rate of decrease of the contact angle of water on the film treated at $10{ }^{\circ} \mathrm{C}$. Therefore, the amount of $\mathrm{SO}_{3}$ groups in the film treated at $25{ }^{\circ} \mathrm{C}$ for 1 hour was expected to be more than the amount of $\mathrm{SO}_{3}$ groups in the film treated at $10^{\circ} \mathrm{C}$ for 1 hour.

For longer treatment time (after 1 hour) however, the contact angle values of the films increase again reaching values slightly higher than those of untreated PP films both at $10{ }^{\circ} \mathrm{C}$ and $25{ }^{\circ} \mathrm{C}$. This behaviour is accounted for by two events. First one, it is probable that partial breakdown of polymer in the film surface was increased with increase in treatment time, and therefore the inner zones of the film were bared. Second one is that, the rough nature of the sulfonated surfaces greatly affects the wetting behaviour. Since the roughness of sulfonated films not only depends on the sulfonation 
process but also strongly depends on the sample preparation, it is not strange that different contact angles are observed on different samples.

\subsection{UV-Visible Analysis Results}

The semitransparent PP film shows a change in surface color with the treatment exceeding 1 hour and also the treatment temperature increases to $120{ }^{\circ} \mathrm{C}$. In Figure $3.2-$ Figure 3.6 the UV-Visible spectra of the untreated PP film and PP films treated at 120 ${ }^{\circ} \mathrm{C}$ for 2, 3, 4 and 5 hours are shown to reflect this effect.

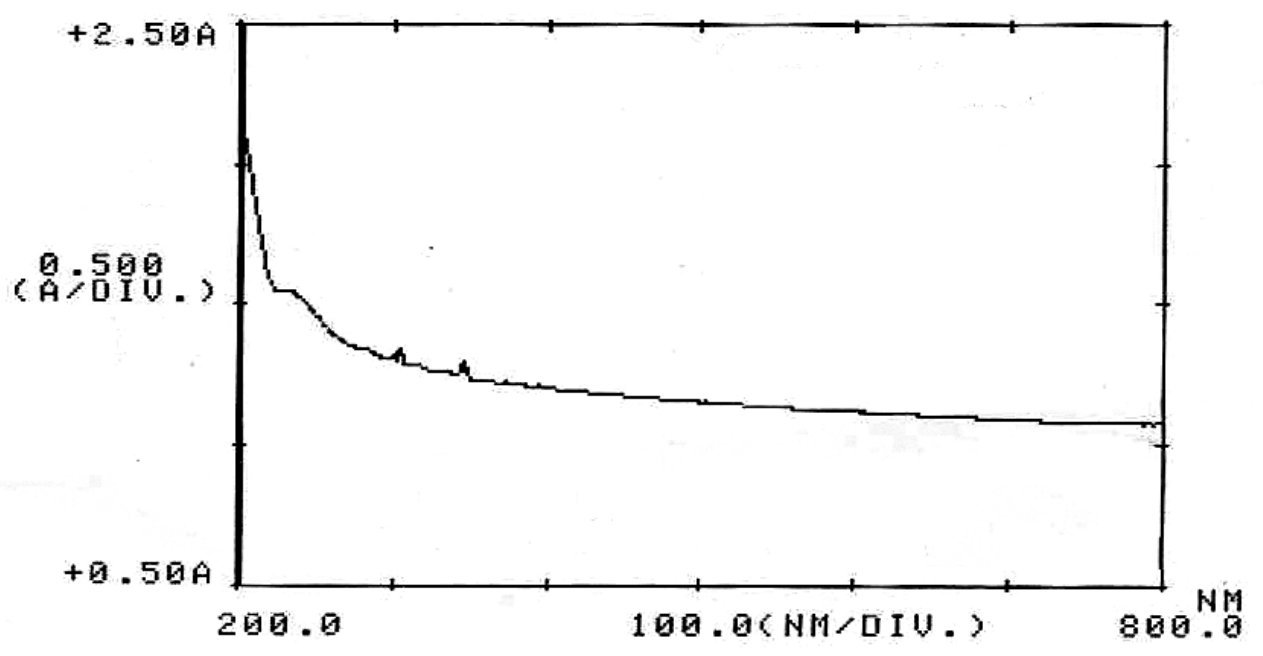

Figure 3.2. The Absorption spectrum of untreated PP film 


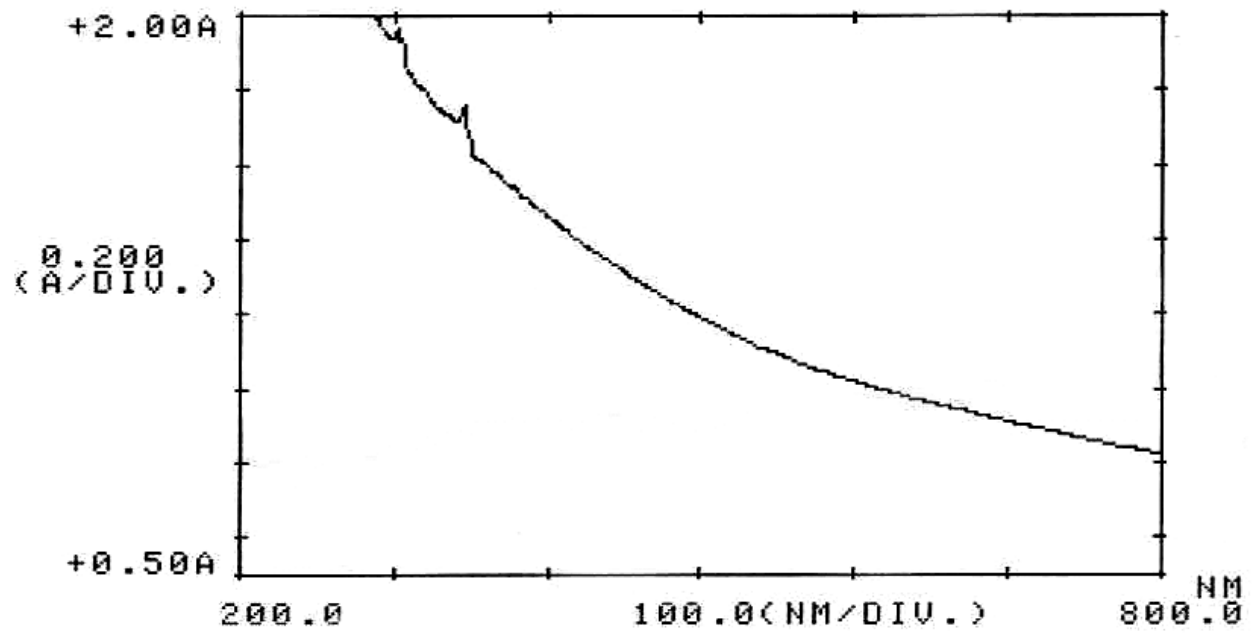

Figure 3.3. The Absorption Spectrum of PP film treated at $120^{\circ} \mathrm{C}$ for 2 hours

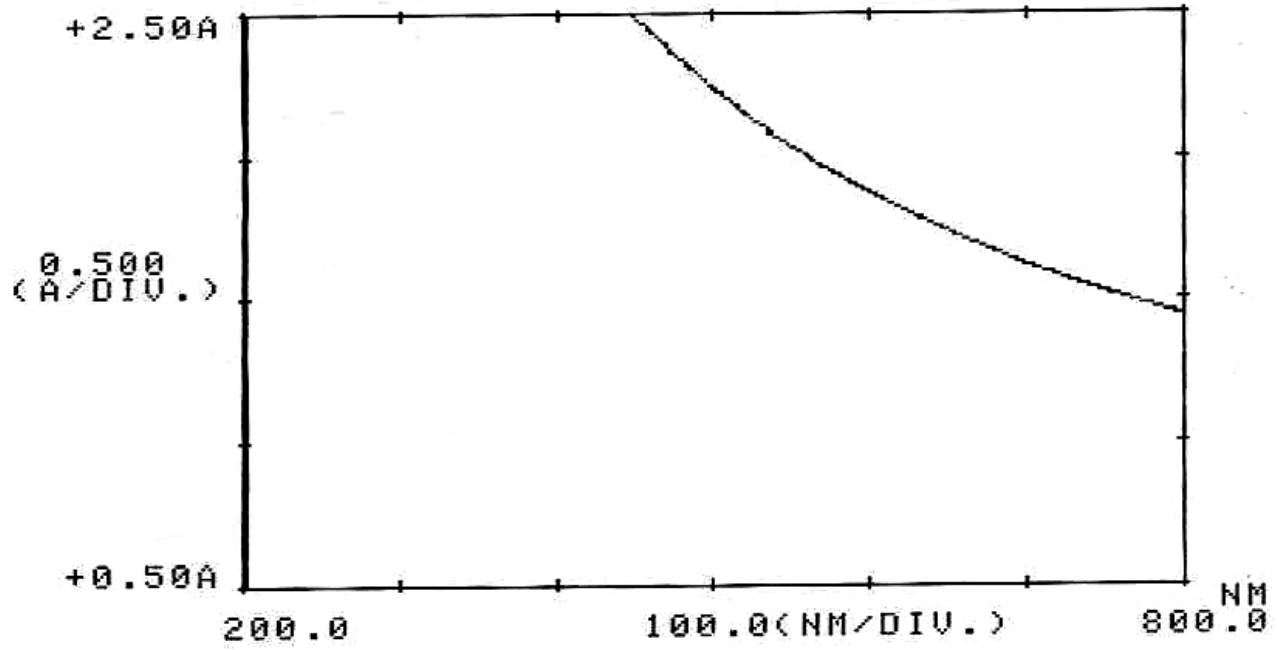

Figure 3. 4. The Absorption Spectrum of PP film treated at $120^{\circ} \mathrm{C}$ for 3 hours 


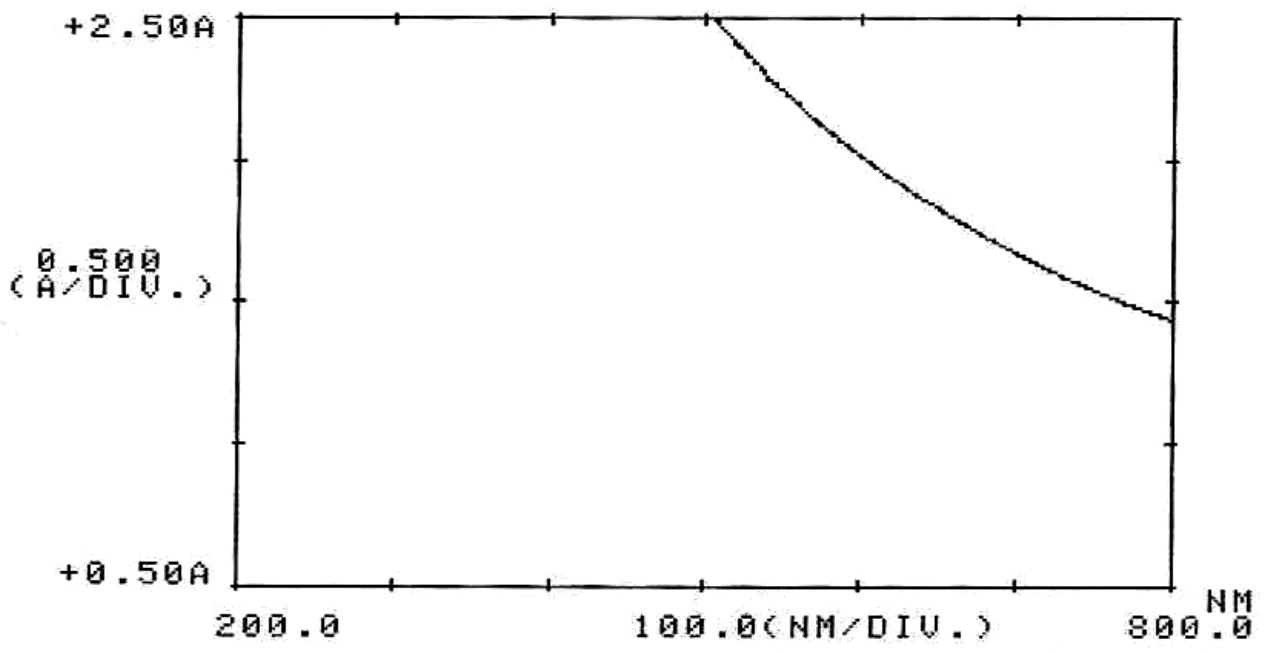

Figure 3.5. The Absorption Spectrum of PP film treated at $120^{\circ} \mathrm{C}$ for 4 hours

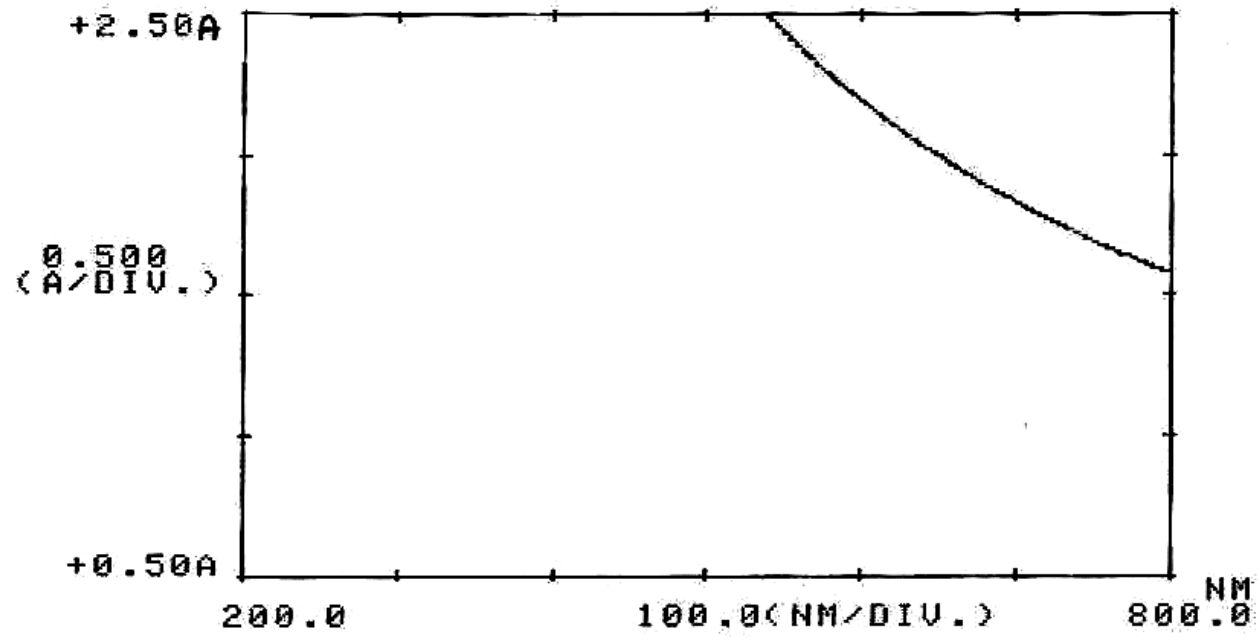

Figure 3.6. The Absorption Spectrum of PP film treated at $120{ }^{\circ} \mathrm{C}$ for 5 hours 
It is clearly seen from the figures that, at $120^{\circ} \mathrm{C}$ as the treatment time increased, the intensity of the absoption region increased compared to the untreated PP films. This is due to the darkening and blackening color of the PP films which can be easily noticed even with naked eye.

The sulfonation of PP revealed to be followed by a significant degree of oxidation, the formation of $\mathrm{C}=\mathrm{C}$ double bonds [21] and also carbonization.

At $120{ }^{\circ} \mathrm{C}$, PP changed its color from white to pale yellow, to dark brown and black by the long time treatment with $\mathrm{H}_{2} \mathrm{SO}_{4}$. This suggests that conjugated $\mathrm{C}=\mathrm{C}$ double bonds responsible for the blackening, are quite difficult to yield in sulfonation of PP films. It is clear from these results that the sulfonation of PP films accompanied by the degradation of PP (formation of $\mathrm{C}=\mathrm{C}$ double bonds ) takes place with hot concentrated $\mathrm{H}_{2} \mathrm{SO}_{4}$ treatment. Indeed, the sulfonation at $25^{\circ} \mathrm{C}$, after 30 minutes the decrease in both $\gamma^{\mathrm{p}}$ and $\gamma^{\mathrm{d}}$ can be accounted as a result of degradation, particularly carbonization process. Furthermore, in the samples sulfonated at $120^{\circ} \mathrm{C}$, the carbonized surface can be easily peeled off when the samples were immersed in hot xylene solution for 2 minutes. This black (or dark brown) surface layer was observed to be brittle, difficult to handle and bend, but the inner layer of PP was apparently untouched and unaffected by the sulfonation process. It can be concluded that the formation of the black layer on the surface act as a protective layer and inhibits further sulfonation deep into the matrix.

\subsection{Mechanical Analysis Results}

The change in mechanical properties of PP and surface sulfonated PP films under different conditions were determined by Lloyd LS 5000 Machine, and the mean values of stress at break and stress at yield are summarized in Table 3.5. 
Table 3.5. Stress at Yield and Break values of untreated and treated PP films

\begin{tabular}{|l|c|c|}
\hline Samples & Stress at Yield (Mpa) & Stress at Break (MPa) \\
\hline PP & 41.629 & 40.145 \\
\hline at $10{ }^{\circ} \mathrm{C}$ for 30 minutes & 38.228 & 35.545 \\
at $10{ }^{\circ} \mathrm{C}$ for 1 hour & 41.396 & 39.413 \\
at $10^{\circ} \mathrm{C}$ for 2 hours & 34.608 & 33.424 \\
at $10{ }^{\circ} \mathrm{C}$ for 3 hours & 38.052 & 36.101 \\
\hline at $25^{\circ} \mathrm{C}$ for 30 minutes & 38.701 & 36.879 \\
at $25^{\circ} \mathrm{C}$ for 1 hour & 36.881 & 35.625 \\
at $25^{\circ} \mathrm{C}$ for 2 hours & 35.094 & 34.086 \\
at $25^{\circ} \mathrm{C}$ for 3 hours & 36.700 & 35.563 \\
\hline at $120^{\circ} \mathrm{C}$ for 30 minutes & 37.946 & 36.541 \\
at $120^{\circ} \mathrm{C}$ for 1 hour & 36.314 & ------- \\
at $120^{\circ} \mathrm{C}$ for 3 hours & ------- & 31.591 \\
at $120^{\circ} \mathrm{C}$ for 4 hours & ------- & 28.222 \\
\hline
\end{tabular}

It is apparent from the table above that, both of these values of treated films are lower than the untreated PP film. Table 3.5. shows that the highest stress at yield and stress at break values belong to the untreated PP. For $10{ }^{\circ} \mathrm{C}$ treatments, it is seen that there are increasing and decreasing values of the these parameters for different periods of $\mathrm{H}_{2} \mathrm{SO}_{4}$ treatments.

As for $25{ }^{\circ} \mathrm{C}$ measurements, the stress at yield and at break values show a decrease with increasing period of $\mathrm{H}_{2} \mathrm{SO}_{4}$ treatment except for the 3 hours treated samples. Degradation is very high at $120^{\circ} \mathrm{C}$ and the samples show very low stress at yield and stress at break values for almost all periods of treatment. 
These results are plotted in Figure 3.7. and Figure 3.8. for stress at break and at yield respectively.The fluctuations are more clearly observed.

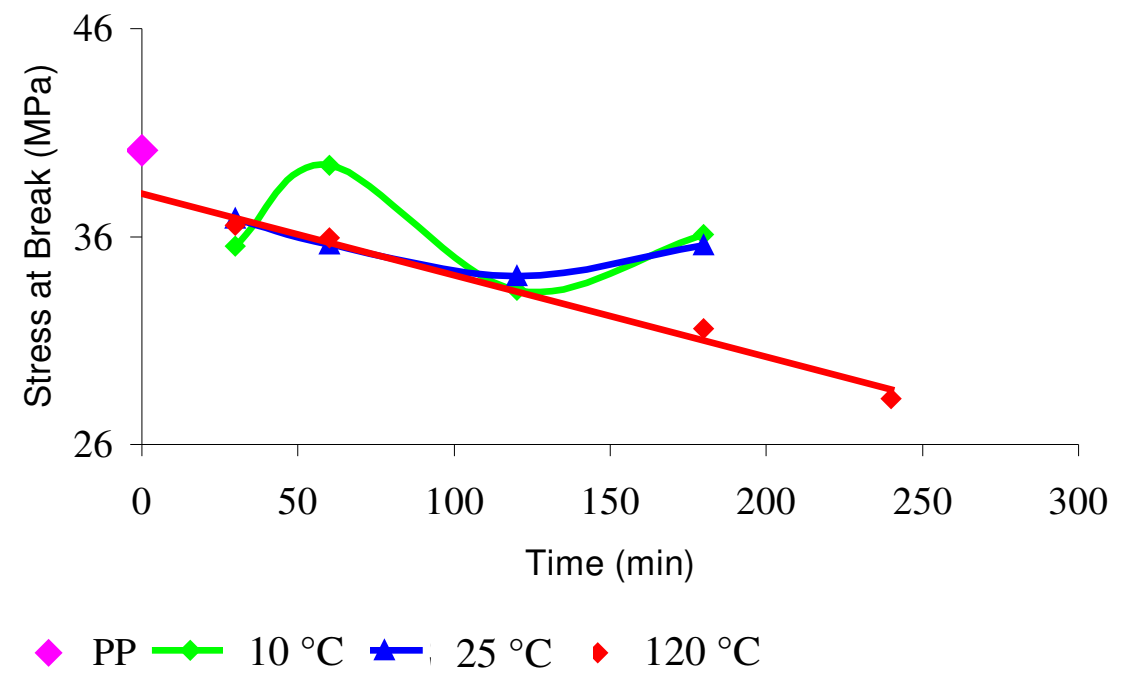

Figure 3.7. Stress at break values vs treatment time at $10{ }^{\circ} \mathrm{C}, 25^{\circ} \mathrm{C}$ and $120{ }^{\circ} \mathrm{C}$

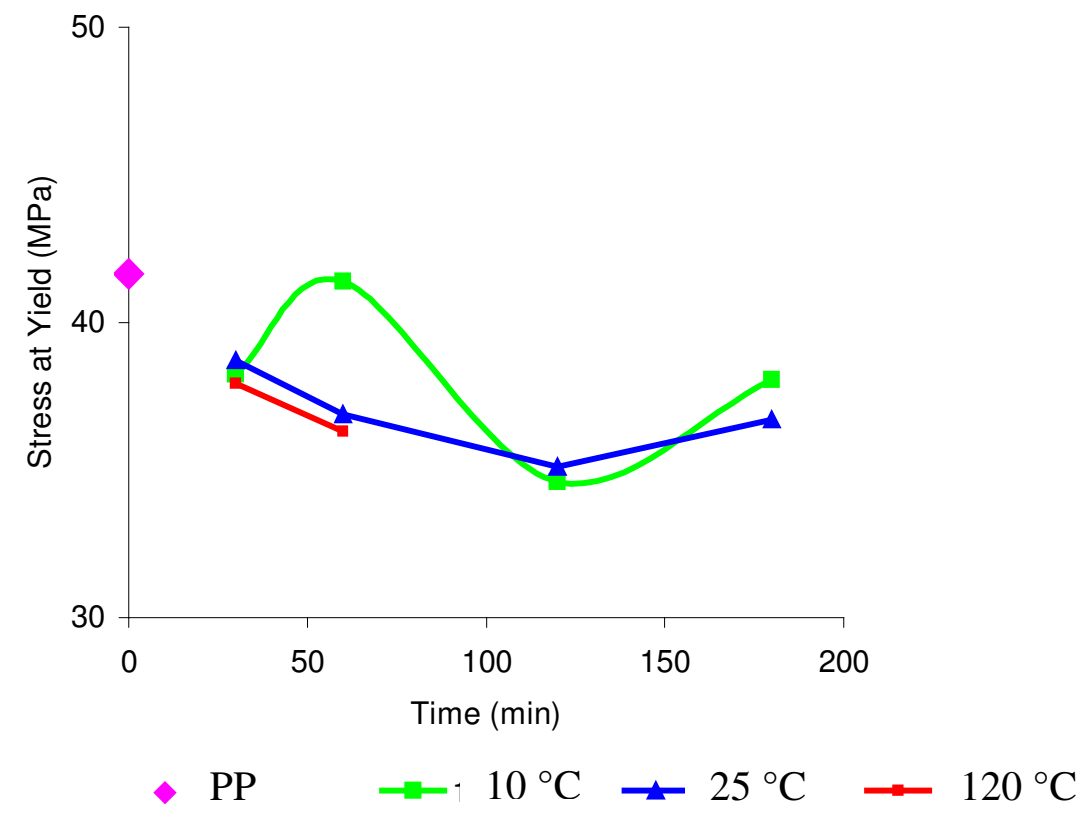

Figure 3.8. Stress at yield values vs treatment time at $10{ }^{\circ} \mathrm{C}, 25^{\circ} \mathrm{C}$ and $120^{\circ} \mathrm{C}$ 
According to Figures 3.7 and 3.8, as the sulfonation time and temperature increase, the stress at break values decrease and become closer to stress at yield values. In the case of temperature increase to $120{ }^{\circ} \mathrm{C}$ for sulfonation process, after 1 hour, the samples broke at the yield point. Consequently, after the sulfonation process the mechanical properties of the PP films show a general trend of decrease with sulfonation time for a given temperature and a very fast decrease at high temmperature of sulfonation.

\subsection{Differential Scanning Calorimeter Results}

Figures $3.9-3.12$ show the DSC thermogram of the untreated PP film and PP films sulfonated at $10{ }^{\circ} \mathrm{C}, 25^{\circ} \mathrm{C}$ and $120{ }^{\circ} \mathrm{C}$ for 1 hour time period respectively.

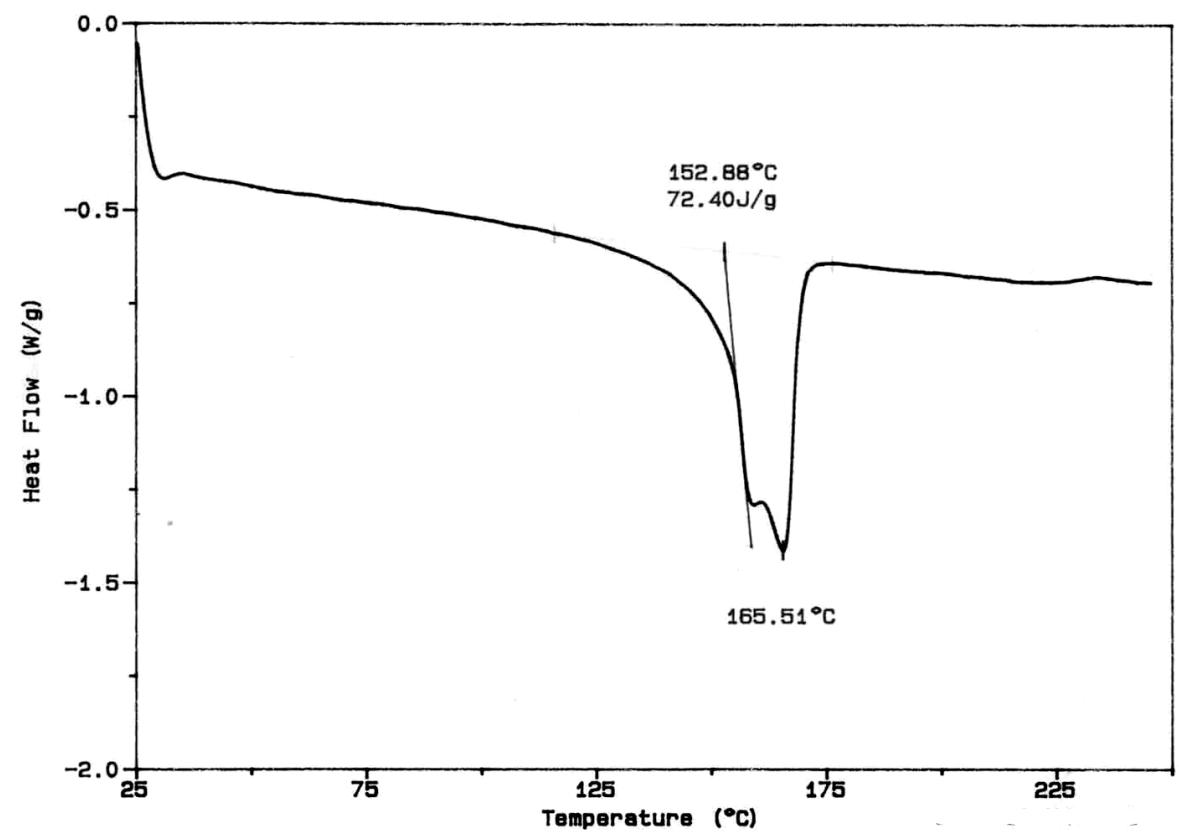

Figure 3.9. DSC thermogram of the untreated PP film 


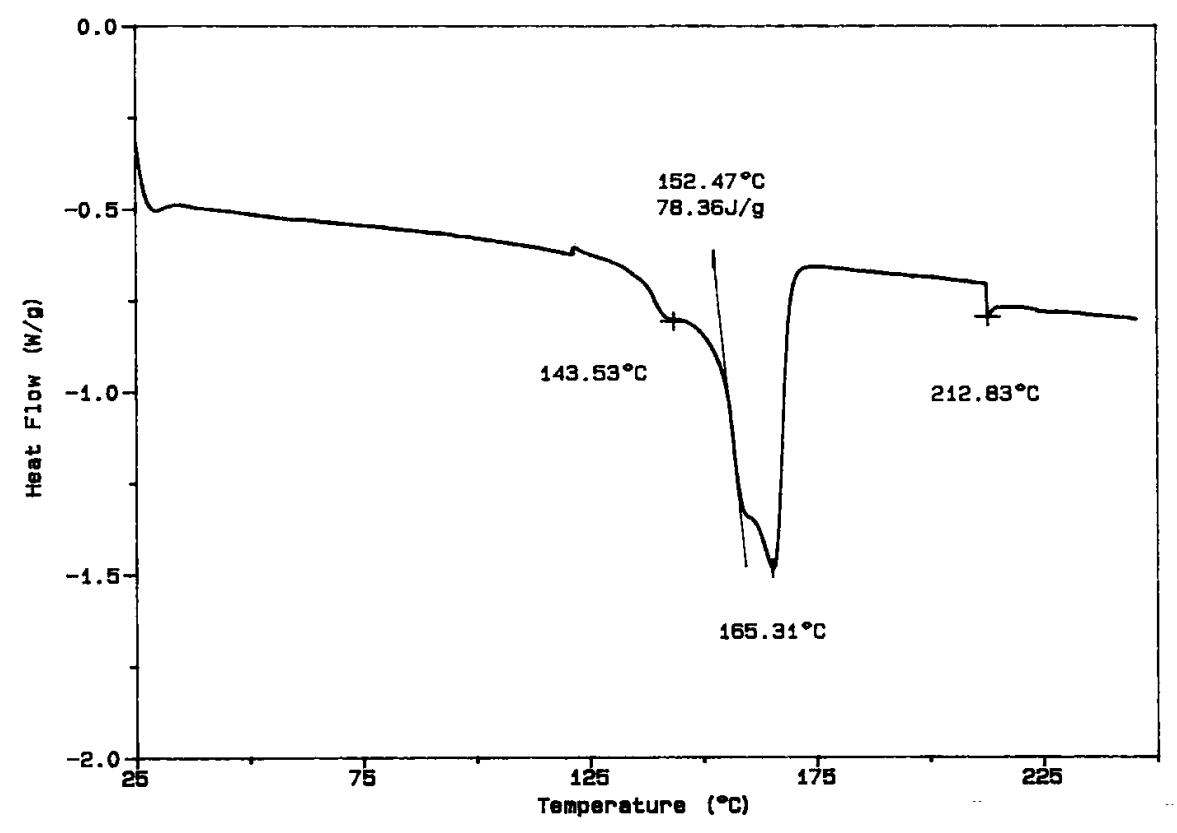

Figure 3.10. DSC thermogram of the PP film treated at $10{ }^{\circ} \mathrm{C}$ for 1 hour

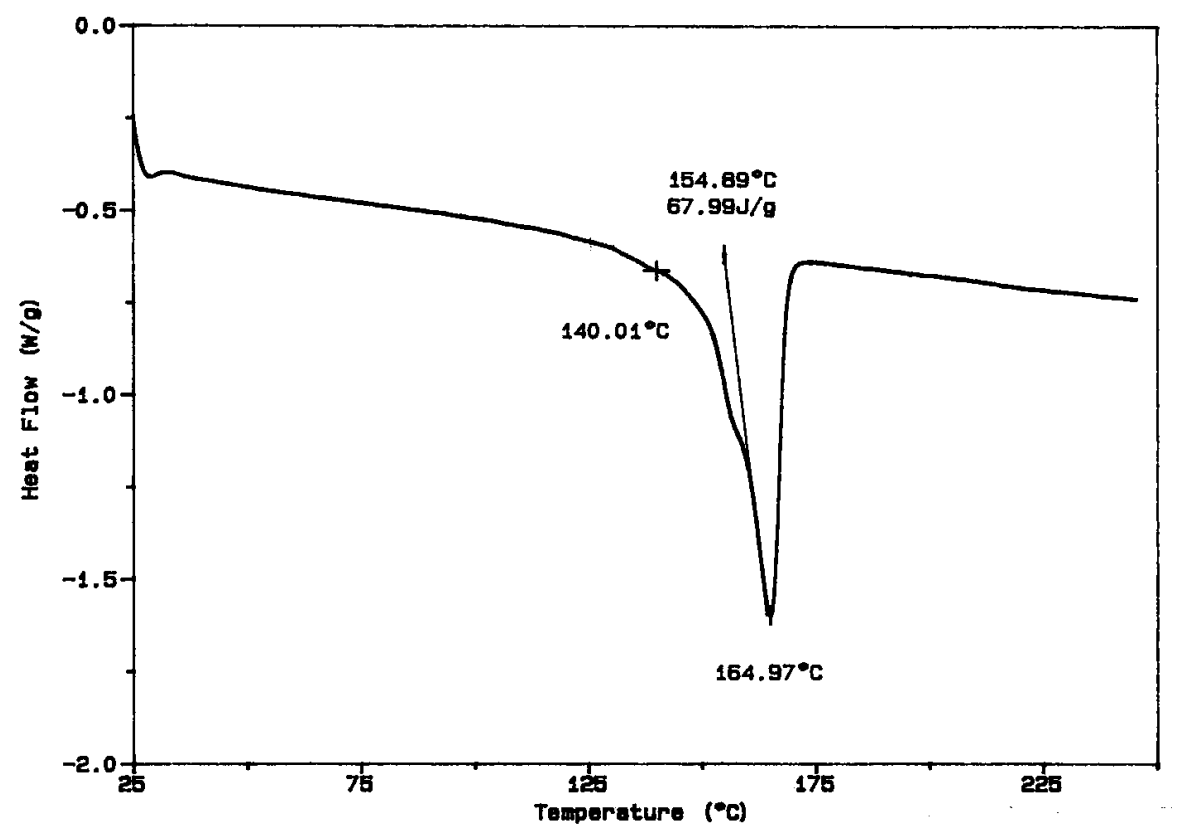

Figure 3.11. DSC thermogram of the PP film treated at $25{ }^{\circ} \mathrm{C}$ for 1 hour 


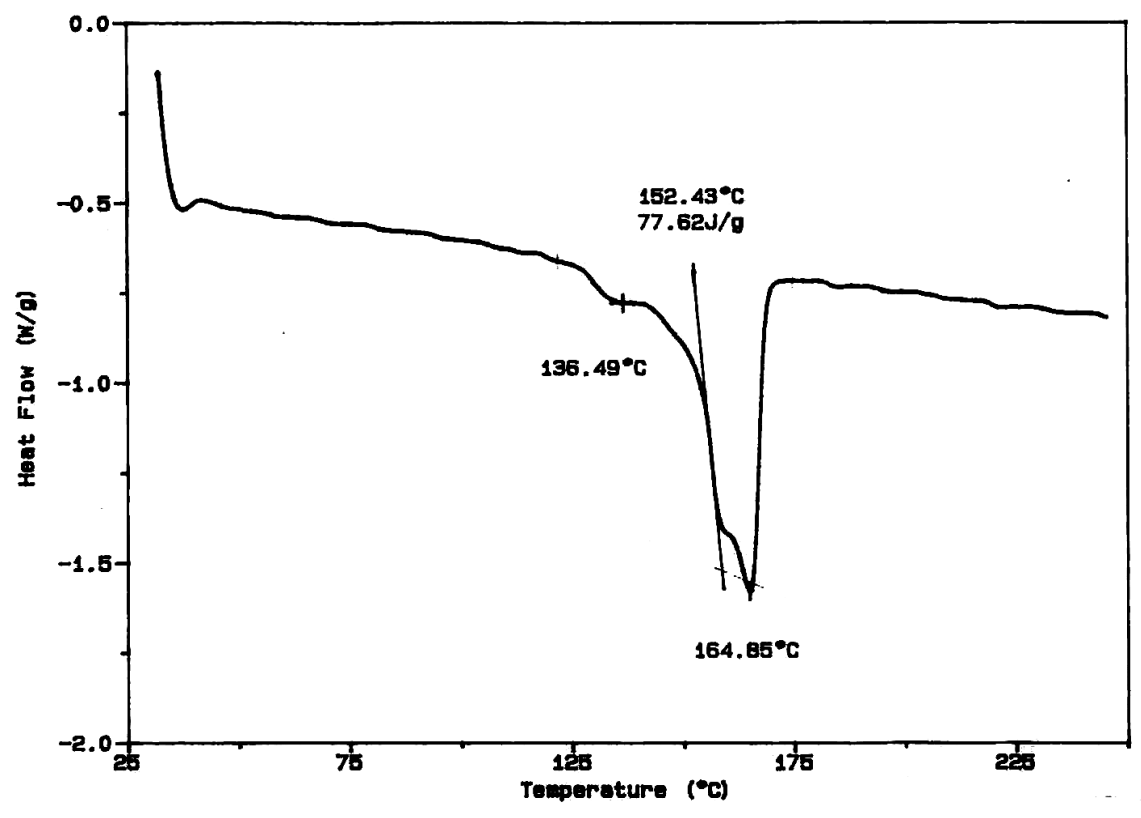

Figure 3.12. DSC thermogram of the PP film treated at $120^{\circ} \mathrm{C}$ for 1 hour

According to the thermograms, between $152{ }^{\circ} \mathrm{C}$ - $165^{\circ} \mathrm{C}$, all samples display the typical PP melting with crystal reorganization(s) due to the polymorphism of polypropylene.

At $10{ }^{\circ} \mathrm{C}$, it is clearly observed that there is a second melting endotherm peak formation before the melting range of the PP due to the sulfonated parts of the PP film. This endotherm peak formation is slightly observed in the DSC thermogram of the samples treated at $25^{\circ} \mathrm{C}$ and $120{ }^{\circ} \mathrm{C}$. It is also seen that, as the sulfonation temperature increased, this thermal behaviour appears at lower temperatures. 


\subsection{Scanning Electron Microscopy Results}

The SEM macrographs of the PP film and sulfonated PP films at different temperatures for different times are given in Figures 3.13 to 3.21.

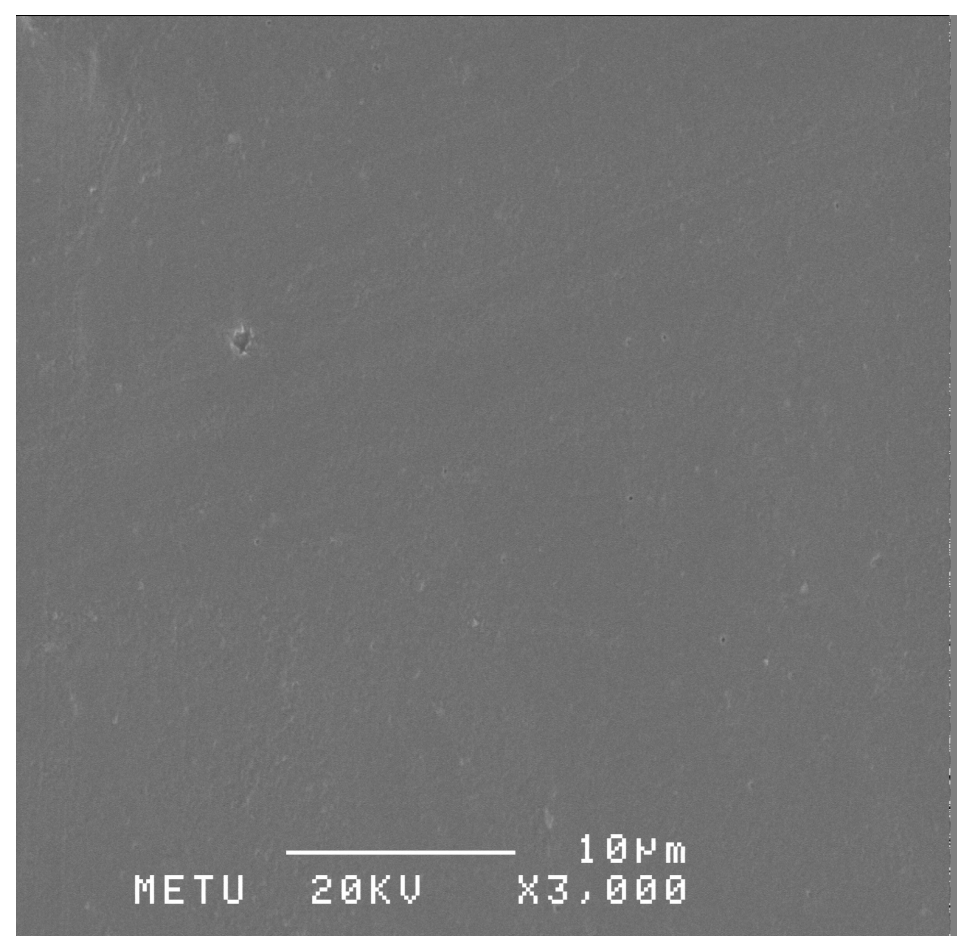

Figure 3.13. The SEM Photograph of PP film treated at $10{ }^{0} \mathrm{C}$ for $30 \mathrm{~min}$. 


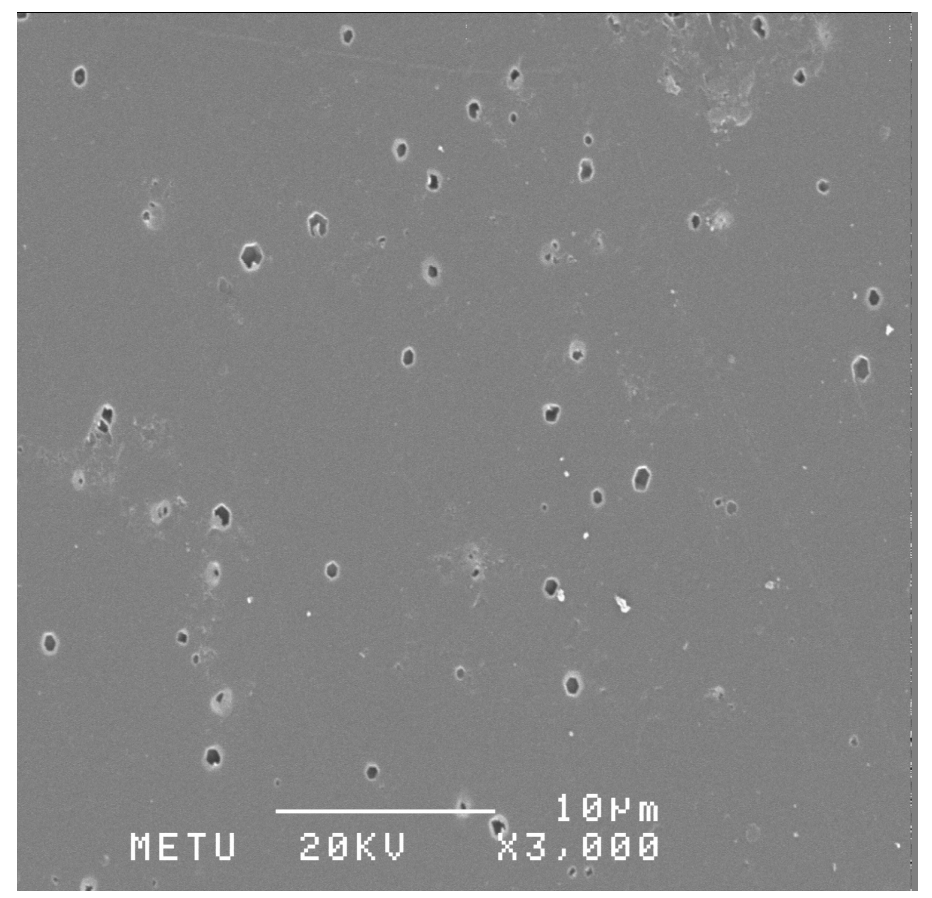

Figure 3.14. The SEM Photograph of PP film treated at $10{ }^{0} \mathrm{C}$ for 3 hours

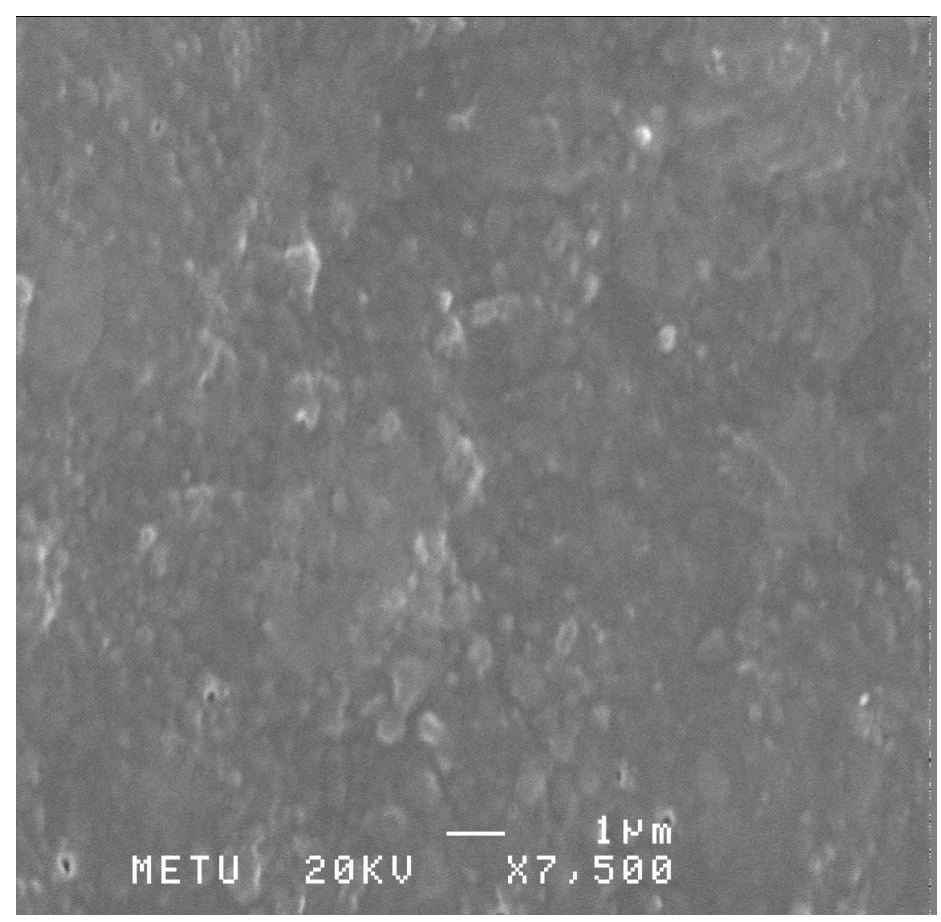

Figure 3.15. The SEM Photograph of PP film treated at $25{ }^{0} \mathrm{C}$ for 3 hours 


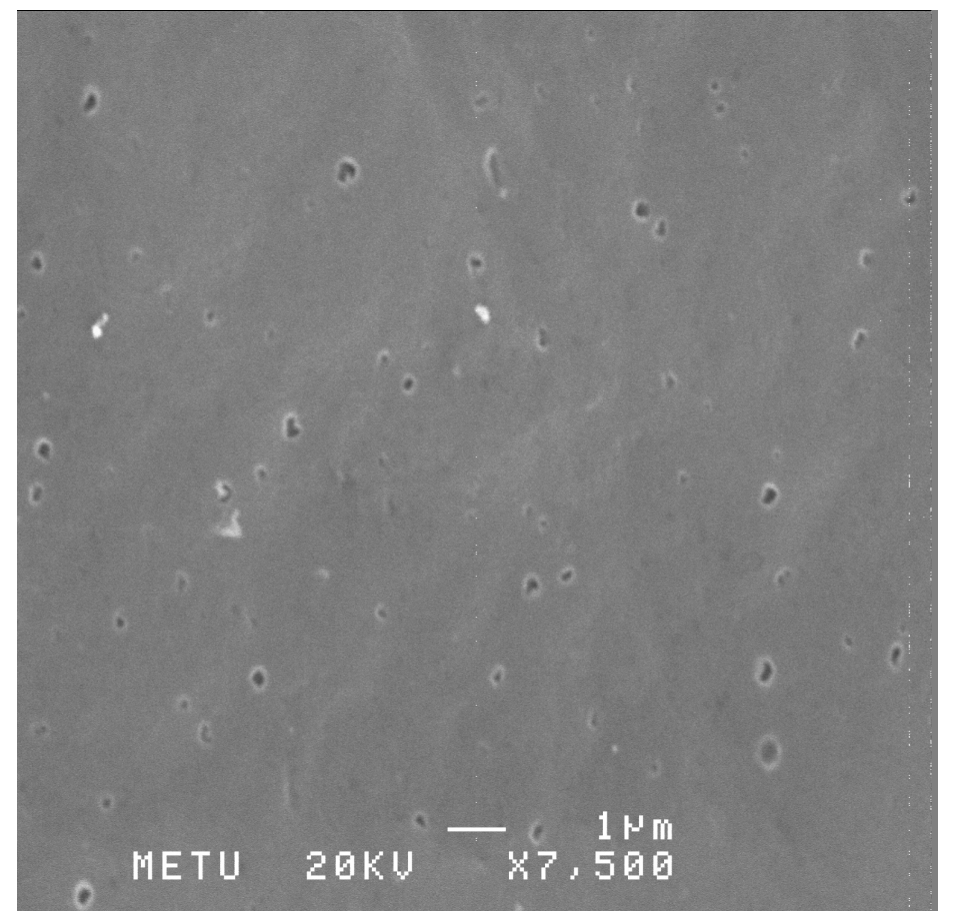

Figure 3.16. The SEM Photograph of PP film treated at $120{ }^{0} \mathrm{C}$ for 1 hour

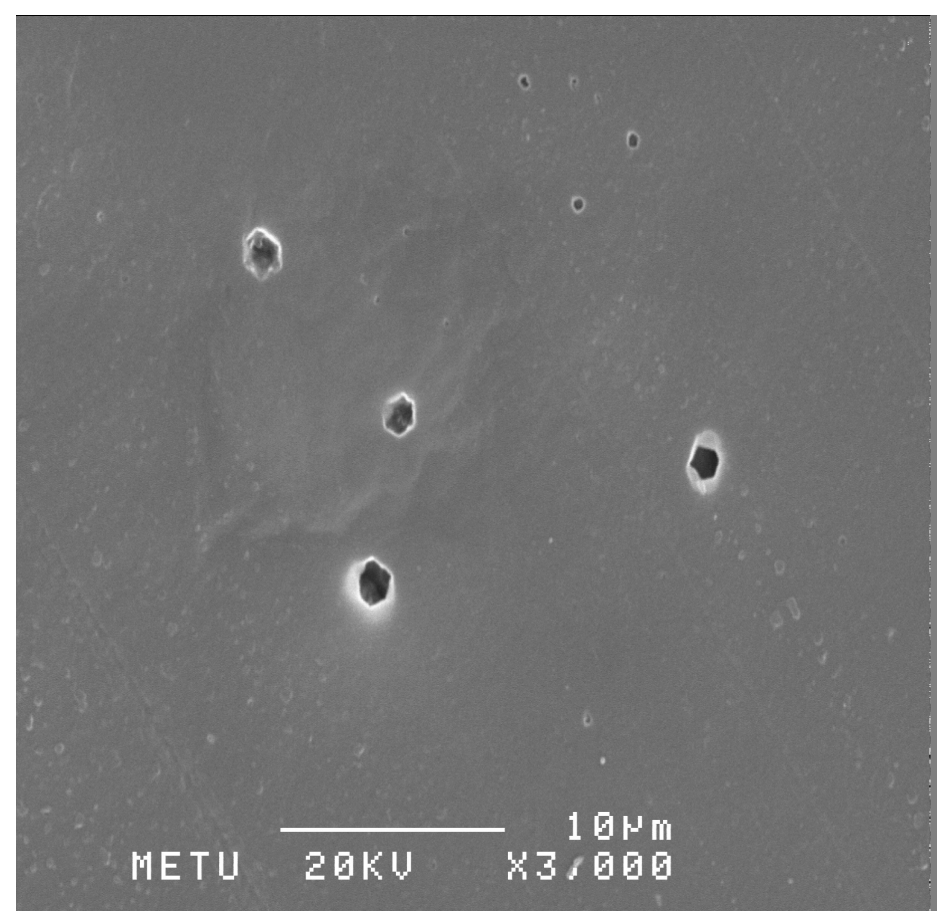

Figure 3.17 The SEM Photograph of PP film treated at $10{ }^{\circ} \mathrm{C}$ for 2 hours 


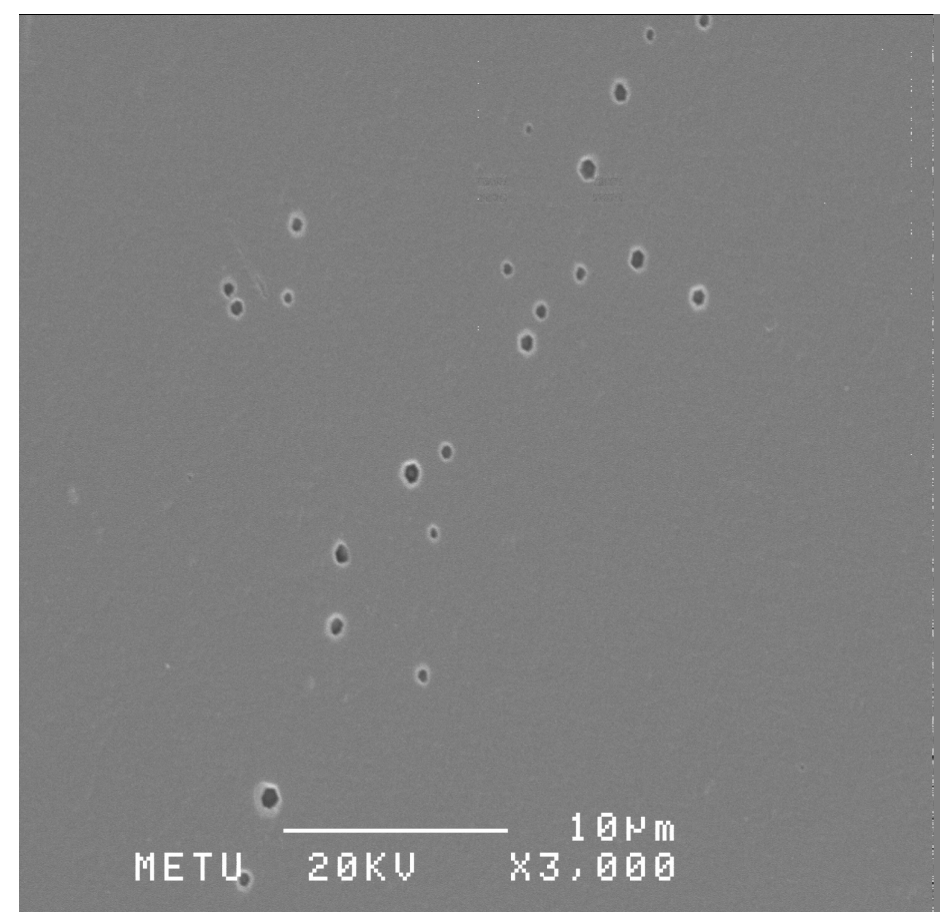

Figure 3.18. The SEM Photograph of PP film treated at $25{ }^{\circ} \mathrm{C}$ for $30 \mathrm{~min}$

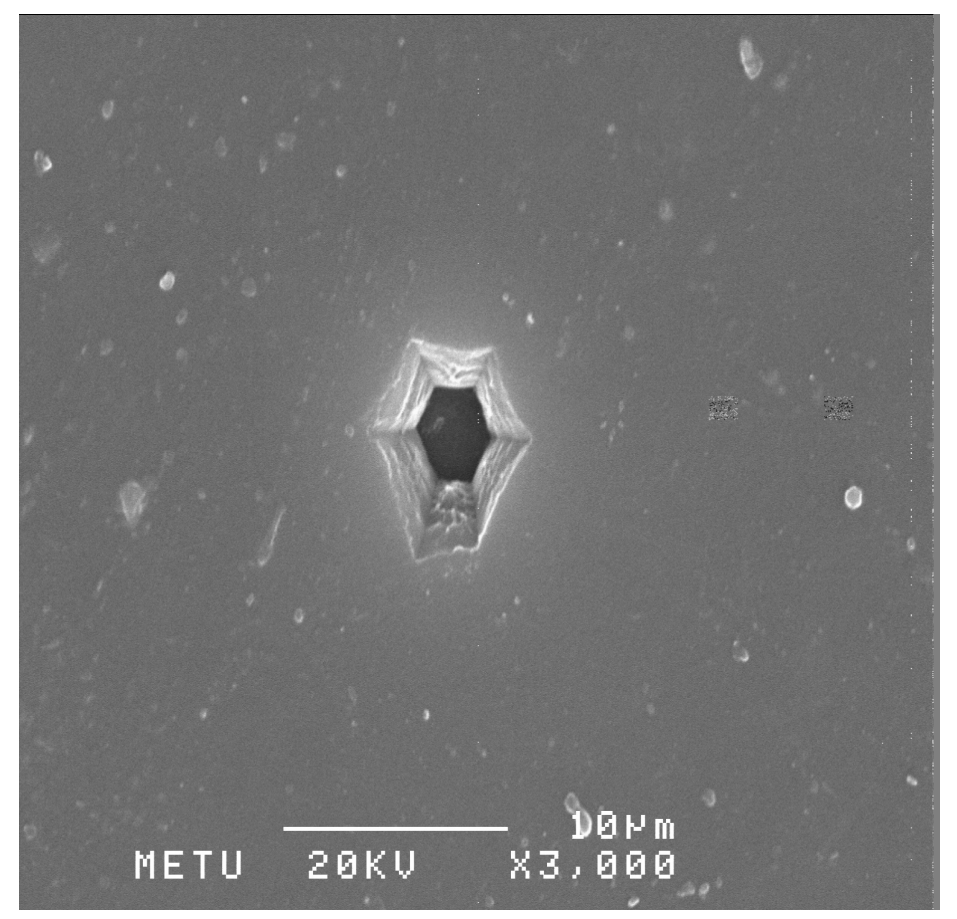

Figure 3.19 The SEM Photograph of PP film treated at $120{ }^{\circ} \mathrm{C}$ for 3 hours 


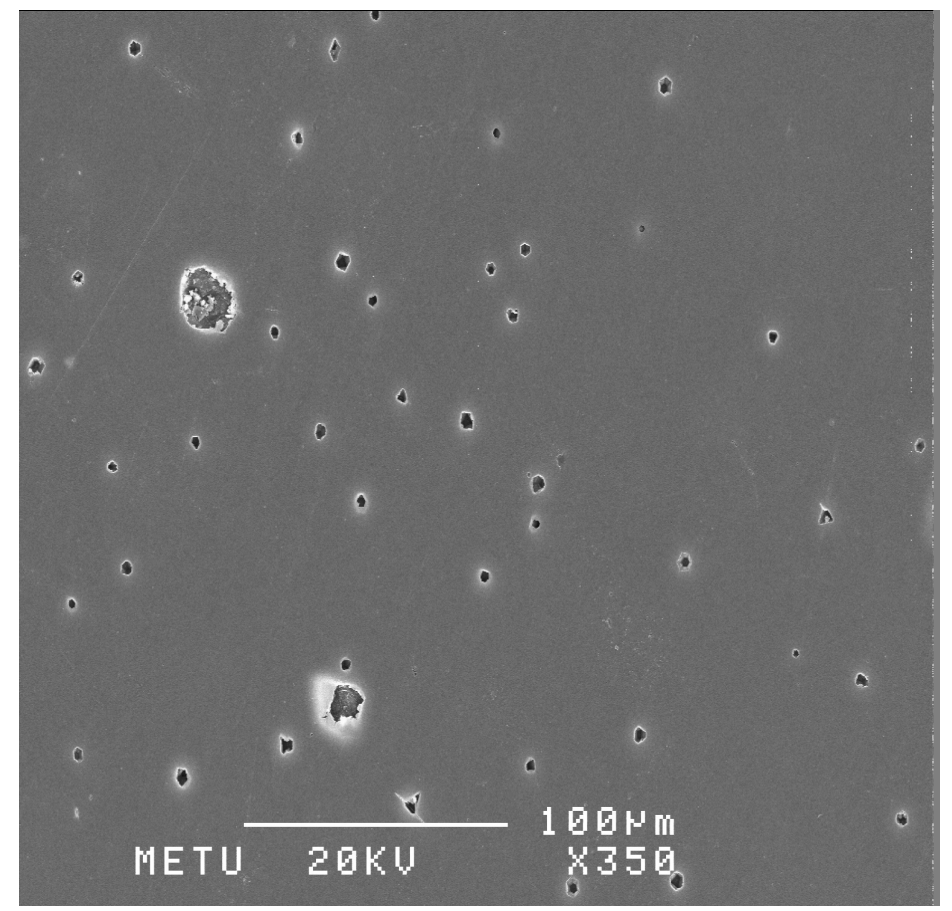

Figure 3.20 The SEM Photograph of PP film treated at $120{ }^{0} \mathrm{C}$ for 4 hours

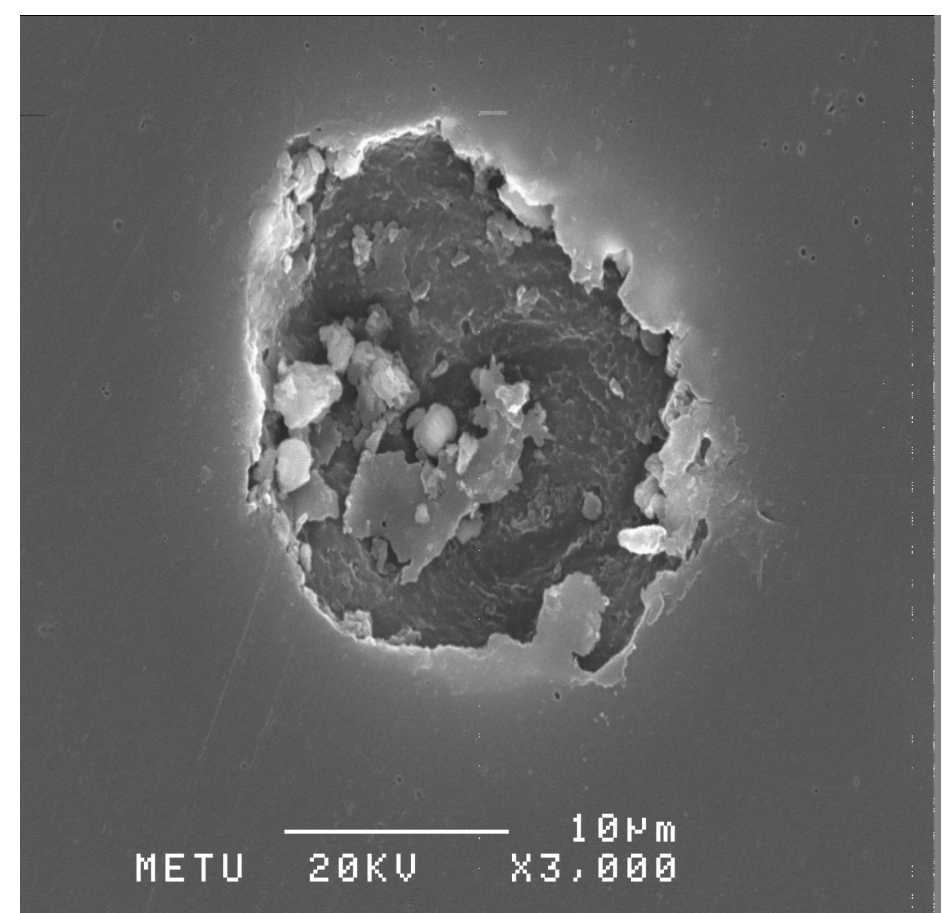

Figure 3.21. The enlarged SEM Photograph of bursted hole at $120{ }^{0} \mathrm{C}$ for $4 \mathrm{hrs}$. 
In general, the film surfaces were observed to be smooth without any cracks of which the formation was shown in some earlier works [15]. However, the submicron holes observed with varying degrees were closely related to the compression moulding process of PP film preparation. These submicron holes after sulfonation procedure were believed to be burst.

Figure 3.14 represents these holes having the size of less than 1 micron, on the surface of the PP films sulfonated for 3 hours at $10{ }^{\circ} \mathrm{C}$. It was also observed that, as the time increases, number of these holes increases. This hole formation could be due to the bursting of the air bubbles, within the PP films, by the effect of sulfonation process.

When the sulfonation temperature increased to $25^{\circ} \mathrm{C}$, a similar picture was seen, Figure $3.15,3.18$. And, at $120^{\circ} \mathrm{C}$, not only the density of these holes increases, but also their size increased to 2-3 micron. One of these holes, which was comperatively very big, having the size of 7 micron, had a perfect hexagonal shape shown in Figure 3.19 Around this hexagonal structure, lamellae formations were clearly observed.

When the above SEM pictures were closely examined and enlarged in computer techniques, it was observed that all holes (big or small) have basically this hexagonal shape.

It is possible to conclude from the SEM photographs that, sulfonation cause bursting on the polymer surface of PP films and as the time and temperature of the treatment increase, bursting density increases. An interesting observation is that eventhough the size of the brusters varier, their shapes are hexagonal and there is formation of lamelae around these hexagonal holes. 


\section{CHAPTER 4}

\section{CONCLUSIONS}

1. According to the contact angle measurement results, it is clearly obvious that, sulfonation process at low tempeatures for short time periods improve the surface polarity and wettability of PP samples. However, the treatments at high temperatures for long time periods cause the degradation of the polymer and carbonization.

2. The trend of the water contact angle values shows that the partial breakdown of the polypropylene film surfaces by degradation seemed to occur with increase in treatment time and temperature.

3. UV-Vis absorption spectra of the PP films support that the degradation of PP films increases with increasing treatment temperature and treatment time for sulfonation process which is noticeable by the darkening color of the PP films that is an indicator of the formation of conjugated $\mathrm{C}=\mathrm{C}$ double bonds.

4. All sulfonated films samples show lower stress at yield and at break values than untreated PP.

5. The values of the stress at yield and at break values display that as the sulfonation time and temperature increased these two values of the PP films become closer and samples broke almost at yield stress. This is due to degra dation of the PP film surfaces by the effect of sulfonation at high temperature and long time period. 
6. The DSC thermogram of the sulfonated samples show an additional endothermic behaviour when compared with the DSC thermogram of the untreated PP; this extra peak which is considered to be due to the sulfonation of PP is most apparent in the sample which is treated at $10{ }^{\circ} \mathrm{C}$ for 1 hour.

7. According to the SEM photographs, the surfaces are observed to be smooth without any craks. However, depending on the sulfonation time and temperature the submicron holes formed by the bursting of the air bubbles within the PP films are observed with lamelea formation around them. 


\section{REFERENCES}

1. Garbassi F., Occhielo E., Polato F., Brown A., J. Mater. Sci.,22, 207, 1987.

2. Carley J. F., Kitze T. P., Polym. Eng. Sci., 18, 326, 1978.

3. Briggs D., Range D. G., Kendal C. R., Blythe A. R., Polym., 21, 895, 1980.

4. Iwata H., Kishida A., Suzuki M., Hata Y., Ikada Y., J. Polym. Sci.Chem. $E d ., 26,3309,1988$.

5. Carrisson D. J., Wiles D. M., Macromolecules, 4, 1974, 1971.

6. Kato K., J. Appl. Polym. Sci., 19, 1593, 1975.

7. Blais P., Day M., Wiles D. M., J. Appl. Polym. Sci., 17, 1895, 1973

8. Rye R. R., J. Polym. Sci. Phys. Ed., 26, 2133, 1988.

9. Kita H., Muraoka M., Tanako K., Okamoto K., Polym. J., 20, 485, 1988.

10. Chan C-M., Polymer Surface Modification and Characterization, Hanser Publishers, Munich, Viana, New York, 1993.

11. Tripathi D., Practical Guide to Polypropylene, Rapra Technology Limited, 2002. 
12. Frank H. P., Polypropylene, Gordon and Breach Science Publishers, N. Y., 1968.

13. Moore Jr. P. E., Polypropylene Handbook, Hanser Publishers, Munich-New York, 1996.

14. Hamid H. S., Amin M. B., Maadhah A. G., Handbook of Polymer Degradation, Marcel Dekker Inc.,1992.

15. Chikh R. B., Askeland P. A., Schalek R. L., Drzal L. T., J. Adhesion Sci. Tech., 16,1251, 2002.

16. Tada H., Ito S. Langmuir, 3, 3982, 1997.

17. Erickson B. L., Asthana H., Drzal L. T., J. Adhesion Sci. Tech., 11, 1249, 1997.

18. Weiss R. A., Chebremeskel Y., Charbornneau L., Polym.,41, 3471, 2000.

19. Mocrini A., Acosta J. L., Polymer, 42, 9, 2001.

20. Allen J. M., Dooley R. L., Shalaby S. W., J. Appl. Polym. Sci., 76, 1865, 2000.

21. Garbassi F., Occihello E., Polato F., Brown A., J. Mater. Sci.,22, 207,1987.

22. Mittal K. L., Polymer Surface Modification: Relevance to Adhesion, Utrecht The Netherlands, 1996. 
23. Bergbreiter D. E., White N., Zhou J., J. Ploym. Sci. Polym. Chem . Ed., 30, 389, 1992.

24. Strobel M.,Corn S., Lyons C. S., Kobra G. A., J. Polym. Sci. Polym. Chem. Ed., 23, 1125, 1985.

25. Laoharojanaphand P., Lin T. J., Stoffer J. O., J. Appl. Polym. Sci., 40, 369, 1990.

26. Yasuda H., Sharma A. K., Yasuda T., J. Polym. Sci. Phys. Ed., 19, 1285, 1981.

27. Yasuda T., Okuno T., Yashida K., Yasuda H., J. Polym. Sci. Phys. Ed., 26, $1781,1988$.

28. Brennar W. J., Feast W. J., Munro H. S., Walker A. S., Polymer, 32, 1527, 1991.

29. Giroux T. A., Cooper S. L., J. Appl. Polym. Sci.,43, 145, 1991.

30. Bayramlı E., Akbay A. R., J. Adhesion, 50, 155, 1995.

31. Shimizu R. N., Demarquette N. R., J. Appl. Polym. Sci., 76, 1831, 200.

32. Wu S., J. Polym. Sci., 19, 34, 1971.

33. The KSV Instruments LTD, web page (

34. Ward I. M., Hadley D. W., An Introduction to the Mechanical Properties of Solid Polymers, Wiley, Chichester, 1993 
